\title{
Nuts and Dried Fruits: An Update of Their Beneficial Effects on Type 2 Diabetes
}

\author{
Pablo Hernández-Alonso ${ }^{1,2}$, Lucía Camacho-Barcia ${ }^{1,2}$, Mònica Bulló ${ }^{1,2, *}$ and \\ Jordi Salas-Salvadó $1,2, *$ \\ 1 Human Nutrition Unit, Biochemistry and Biotechnology Department, Faculty of Medicine and Health \\ Sciences, University Hospital of Sant Joan de Reus, IISPV, Universitat Rovira i Virgili, St/Sant Llorenç 21, \\ 43201 Reus, Spain; pablo1280@gmail.com (P.H.-A.); marialucia.camacho@urv.cat (L.C.-B.) \\ 2 CIBERobn Physiopathology of Obesity and Nutrition, Instituto de Salud Carlos III, 28029 Madrid, Spain \\ * Correspondence: monica.bullo@urv.cat (M.B.); jordi.salas@urv.cat (J.S.-S.); \\ Tel.: +34-977-759-312 (M.B.); +34-977-759-311 (J.S.-S.)
}

Received: 24 May 2017; Accepted: 22 June 2017; Published: 28 June 2017

\begin{abstract}
Nuts and dried fruit are essential foods in the Mediterranean diet. Their frequent consumption has been associated with the prevention and/or the management of such metabolic conditions as type 2 diabetes (T2D), metabolic syndrome and cardiovascular diseases. Several previous reviews of epidemiological studies and clinical trials have evaluated the associations of nuts and/or dried fruit with various metabolic disorders. However, no reviews have focused on the mechanisms underlying the role of nuts and/or dried fruit in insulin resistance and T2D. This review aims to report nut and dried-fruit nutritional interventions in animals and humans, and to focus on mechanisms that could play a significant role in the prevention and treatment of insulin resistance and T2D.
\end{abstract}

Keywords: diabetes; nuts; dried fruits; insulin resistance; mechanisms; clinical trials

\section{Introduction}

Nuts and traditional dried fruit (i.e., with no added sugar) are key food categories in the Mediterranean diet and other regional diets [1]. Several prospective studies, clinical trials and research in animals have reported beneficial effects after nut consumption [2]. However, the benefits of dried fruits (DF), mainly raisins, have been less explored [3].

Over time, food consumption has varied. More than 30 years ago, the consumption of nuts and DF was discouraged because of their high fat and sugar content, respectively. However, at the beginning of the 1990s, several randomized clinical trials (RCT) and animal experiments demonstrated their potential beneficial effect on cardiovascular diseases (CVD). Nuts and DF contain various macro and micronutrients together with other important bioactive compounds that may synergically contribute to modulate specific metabolic diseases such as hypercholesterolemia, hypertension and type 2 diabetes (T2D) (reviewed in $[3,4]$ ). Even so, the specific role of nuts and DF in the development and progression of insulin resistance (IR) and T2D are still controversial.

In this review, we focus on the role of nuts and DF in the prevention and treatment of T2D. We summarize published in vivo, in vitro, epidemiological and clinical studies, and we review the potential mechanisms that could explain the beneficial role of nut consumption on glucose and insulin metabolism, both of which are altered in T2D and in other glucose-impaired states. Given that the present article is not a systematic review, we may not have identified some studies and publication bias should be acknowledged. However, all authors independently conducted the literature search. 


\subsection{Nuts and Dried Fruits: The Concept}

\subsubsection{Nuts}

Nuts have been part of the human diet since prehistoric times $[5,6]$. They are an independent food group and are one of the cornerstones of the Mediterranean diet (MedDiet) [7]. According to the botanical definition, a nut is simply a dried fruit with one seed (rarely two) in which the ovary walls are very hard (stony or woody) at maturity, and the seed is unattached or free within the ovary wall. However, the word "nut" is commonly used to refer to any large, oily kernel in a shell that can be eaten as food. In this review, we use the term "nuts" to refer to almonds, Brazil nuts, cashews, hazelnuts, macadamias, peanuts, pecans, pine nuts, pistachios and walnuts. Although peanuts are actually classified as legumes because of their similar nutrient composition and their proven cardiovascular health benefits, they are commonly regarded as being a nut.

\subsubsection{Dried Fruits}

To extend their shelf life, fresh fruits are processed by various techniques to become DFs [3]. Dried fruits are a concentrated form of fresh fruits with a lower moisture content. Fruits can be dried whole (e.g., apricots, berries and grapes), in halves, or in slices (e.g., kiwis, mangoes and papayas). In this form, they are easy to store and distribute, they can be available throughout the year, and they are a healthier alternative to salty or sugary snacks. Apples, apricots, currants, dates, figs, peaches, pears, prunes, and raisins are referred to as "conventional" or "traditional" DFs. Meanwhile, such fruits as blueberries, cranberries, cherries, strawberries and mangoes are commonly infused with different types of sugar solution (or fruit juice) concentrate before drying [8] so are not included in the aforementioned category. Moreover, we have also excluded dried tomato because although it is botanically a berry-type fruit, it is culinary considered a vegetable and it shares nutrient composition with this food category.

\subsection{Nutritional Composition of Nuts and Dried Fruits}

Nuts and DFs are a matrix of important bioactive compounds such as Vitamins (Vitamin E, niacin, choline and/or folic acid), minerals (magnesium, potassium, calcium and/or phosphorus), phenolic compounds, carotenoids and/or phytosterols [9]. Importantly, some nuts and DFs are among the 50 foods with the highest antioxidant capacity [10] and are also a known source of bioactive compounds, including plant sterols [11]. Pistachios are particularly rich in $\beta$-carotenes which have been widely associated with a protective T2D role $[12,13]$. In addition, pistachios are the only nuts that contain significant amounts of lutein and zeaxanthin [9]. Sun-dried raisins retain the minerals and most of the phytochemicals and antioxidants of the grape, including its resveratrol $[14,15]$. In fact, sun-drying enhances the antioxidant content of raisins. Because of the dehydration process, phytonutrients are more concentrated in raisins than in grapes. However, the concentration of some compounds is decreased by the sun-drying process in DFs and by dry roasting techniques in nuts [9]. Polyphenols and tocopherols from nuts and DF have proved to be rapidly accessible in the stomach, thus maximizing the possibility of absorption in the upper small intestine, and contributing to the beneficial relation between nut and DF consumption and health-related outcomes [8,16].

However, their macronutrient compositions are quite different, which means that their energy contents are also quite different. Nuts contain a high amount of total fat (Range (Re): 43.9-78.8\%) with a high amount of unsaturated fat (monounsaturated fatty acids (MUFA) + polyunsaturated fatty acids (PUFA), Re: 31.6-62.4\%), a relatively low amount of carbohydrates (CHOs) (Re: 11.7-30.2\%) and vegetable protein (Re: $7.9-25.8 \%$ ) (Table 1).

Conversely, DFs are mainly composed of CHOs (Re: 61.3-72.8\%). They have a low content of protein (Re: $0.17-4.08 \%$ ) and a fat content of less than $1 \%$ (Table 2). Importantly, both foods also contain a considerable amount of dietary fiber. Overall, their unique and varied nutrient composition makes them key foods to counteract various metabolic diseases. 
Table 1. Nutrient composition of nuts (per $100 \mathrm{~g}$ of raw nut).

\begin{tabular}{|c|c|c|c|c|c|c|c|c|c|c|}
\hline Nutrient & Almonds & Brazil Nuts ${ }^{b}$ & Cashews & Hazelnuts & Macadamias & Peanuts & Pecans & Pine Nuts ${ }^{b}$ & Pistachios & Walnuts \\
\hline Energy, Kcal & 579 & 659 & 553 & 628 & 718 & 567 & 691 & 673 & 560 & 654 \\
\hline Water, $\mathrm{g}$ & 4.4 & 3.4 & 5.2 & 5.3 & 1.4 & 6.5 & 3.5 & 2.3 & 4.4 & 4.1 \\
\hline Fat, $\mathrm{g}$ & 49.9 & 67.1 & 43.9 & 60.8 & 75.8 & 49.2 & 72.0 & 68.4 & 45.3 & 65.2 \\
\hline SFA, $\mathrm{g}$ & 3.8 & 16.1 & 7.8 & 4.5 & 12.1 & 6.3 & 6.2 & 4.9 & 5.9 & 6.1 \\
\hline MUFA, $\mathrm{g}$ & 31.6 & 23.9 & 23.8 & 45.7 & 58.9 & 24.4 & 40.8 & 18.8 & 23.3 & 9.0 \\
\hline PUFA, $\mathrm{g}$ & 12.3 & 24.4 & 7.8 & 7.9 & 1.5 & 15.6 & 21.6 & 34.1 & 14.4 & 47.2 \\
\hline Protein, $\mathrm{g}$ & 21.2 & 14.3 & 18.2 & 15.0 & 7.9 & 25.8 & 9.2 & 13.7 & 20.2 & 15.2 \\
\hline $\mathrm{CHO}, \mathrm{g}$ & 21.6 & 11.7 & 30.2 & 16.7 & 13.8 & 16.1 & 13.9 & 13.1 & 27.2 & 13.7 \\
\hline Fiber, $\mathrm{g}$ & 12.5 & 7.5 & 3.3 & 9.7 & 8.6 & 8.5 & 9.6 & 3.7 & 10.6 & 6.7 \\
\hline $\mathrm{Ca}, \mathrm{mg}$ & 269 & 160 & 37 & 114 & 85 & 92 & 70 & 16 & 105 & 98 \\
\hline $\mathrm{Mg}, \mathrm{mg}$ & 270 & 376 & 292 & 163 & 130 & 168 & 121 & 251 & 121 & 158 \\
\hline $\mathrm{Na}, \mathrm{mg}$ & 1 & 3 & 12 & 0 & 5 & 18 & 0 & 2 & 1 & 2 \\
\hline $\mathrm{K}, \mathrm{mg}$ & 733 & 659 & 660 & 680 & 368 & 705 & 410 & 597 & 1025 & 441 \\
\hline $\mathrm{P}, \mathrm{mg}$ & 481 & 725 & 593 & 290 & 188 & 376 & 277 & 575 & 490 & 346 \\
\hline Lutein-Zeaxanthin, $\mu \mathrm{g}$ & 1 & 0 & 22 & 92 & NA & 0 & 17 & 9 & 2903 & 9 \\
\hline$\beta$-Carotene, $\mu \mathrm{g}$ & 1 & 0 & 0 & 11 & NA & 0 & 29 & 17 & 305 & 12 \\
\hline$\alpha$-Carotene, $\mu \mathrm{g}$ & 0 & 0 & 0 & 3 & NA & 0 & 0 & 0 & 10 & 0 \\
\hline Phytosterols a $\mathrm{mg}$ & 197 & 123.5 & 151 & 122 & 116 & NA & 158.8 & 236.1 & 214 & 110.2 \\
\hline Total phenols, mg & 287 & 244 & 137 & 687 & 126 & 406 & 1284 & 32 & 867 & 1576 \\
\hline Vitamin E ( $\alpha$-tocopherol), mg & 25.6 & 5.7 & 0.9 & 15.0 & 0.5 & 8.3 & 1.4 & 9.3 & 2.9 & 0.7 \\
\hline
\end{tabular}

min E ( $\alpha$-tocopherol), mg 25.6

monounsaturated fatty acids; NA: not available; PUFA, polyunsaturated fatty acids; SFA, saturated fatty acids. ${ }^{\text {a }}$ Phytosterols, are the sum of stigmasterol, campesterol, $\beta$-sitosterol and other phytosterols; ${ }^{\mathrm{b}}$ dry roasted; ${ }^{\mathrm{c}}$ English variety. 
Table 2. Nutrient composition of dried fruits (per $100 \mathrm{~g}$ ).

\begin{tabular}{|c|c|c|c|c|c|c|c|c|c|c|}
\hline Nutrient & Apples $^{a}$ & Apricots $^{a}$ & Currants (Zante) & Cranberries ${ }^{b}$ & Dates $^{c}$ & Figs & Peaches $^{a}$ & Pears $^{a}$ & Plums/Prunes & Raisins $^{d}$ \\
\hline Energy, Kcal & 243 & 241 & 283 & 308 & 282 & 249 & 239 & 262 & 240 & 299 \\
\hline Water, $\mathrm{g}$ & 31.76 & 30.89 & 19.21 & 15.79 & 20.53 & 30.05 & 31.80 & 26.69 & 30.92 & 15.43 \\
\hline Fat, $\mathrm{g}$ & 0.32 & 0.51 & 0.27 & 1.09 & 0.39 & 0.93 & 0.76 & 0.63 & 0.38 & 0.46 \\
\hline $\mathrm{CHO}, \mathrm{g}$ & 65.89 & 62.64 & 74.08 & 82.80 & 75.03 & 63.87 & 61.33 & 69.70 & 63.88 & 79.18 \\
\hline Sugars, $\mathrm{g}$ & 57.19 & 53.44 & 67.28 & 72.56 & 63.35 & 47.92 & 41.74 & 62.20 & 38.13 & 59.19 \\
\hline Fructose, $\mathrm{g}$ & NA & 12.47 & NA & 26.96 & 19.56 & 22.93 & 13.49 & NA & 12.45 & 29.68 \\
\hline Protein, $\mathrm{g}$ & 0.93 & 3.39 & 4.08 & 0.17 & 2.45 & 3.30 & 3.61 & 1.87 & 2.18 & 3.07 \\
\hline Fiber, $\mathrm{g}$ & 8.7 & 7.3 & 6.8 & 5.3 & 8.0 & 9.8 & 8.2 & 7.5 & 7.1 & 3.7 \\
\hline $\mathrm{Ca}, \mathrm{mg}$ & 14 & 55 & 86 & 9 & 39 & 162 & 28 & 34 & 43 & 50 \\
\hline $\mathrm{Fe}, \mathrm{mg}$ & 1.40 & 2.66 & 3.26 & 0.39 & 1.02 & 2.03 & 4.06 & 2.10 & 0.93 & 1.88 \\
\hline $\mathrm{Mg}$, mg & 16 & 32 & 41 & 4 & 43 & 68 & 42 & 33 & 41 & 32 \\
\hline $\mathrm{Na}, \mathrm{mg}$ & 87 & 10 & 8 & 5 & 2 & 10 & 7 & 6 & 2 & 11 \\
\hline $\mathrm{K}, \mathrm{mg}$ & 450 & 1162 & 892 & 49 & 656 & 680 & 996 & 533 & 732 & 749 \\
\hline $\mathrm{Cu}, \mathrm{mg}$ & 0.19 & 0.34 & 0.47 & 0.06 & 0.21 & 0.29 & 0.36 & 0.37 & 0.28 & 0.32 \\
\hline$\beta$-carotene, $\mu \mathrm{g}$ & 0 & 2163 & 43 & 27 & 6 & 6 & 1074 & 2 & 394 & 0 \\
\hline$\alpha$-carotene, $\mu \mathrm{g}$ & 0 & 0 & 1 & 0 & 0 & 0 & 3 & 0 & 57 & 0 \\
\hline Lutein-Zeaxanthin, $\mu \mathrm{g}$ & 0 & 0 & 0 & 138 & 75 & 32 & 559 & 50 & 148 & 0 \\
\hline Vitamin A, IU & 0 & 3604 & 73 & 46 & 10 & 10 & 2163 & 3 & 781 & 0 \\
\hline Total phenols, mg GAE/100g e & 324 & 248 & NA & NA & 661 & 960 & 283 & 679 & 938 & 1065 \\
\hline
\end{tabular}

Data is for traditional dried fruits which is defined as those with no added sugars, typically sun-dried or dried with minimal processing. Nutrient information is taken from the United States Department of Agriculture (USDA) Nutrient Database Standard Reference, Release 28 [9]. CHO, carbohydrates; GAE, gallic acid equivalents; IU, international unit; NA, not available. ${ }^{a}$ Sulfured; ${ }^{b}$ sweetened; ${ }^{\mathrm{c}}$ Deglet noor is the common variety; ${ }^{\mathrm{d}}$ seedless; ${ }^{\mathrm{e}}$ Total phenol content was obtained from Alasalvar and Shahidi [8]. 


\subsection{Diet Quality in the Context of Nut and Dried Fruit Consumption}

Epidemiological studies conducted in children and adults have demonstrated a significant positive association between nut consumption and diet quality $[17,18]$. Furthermore, the results of a clinical trial conducted in obese $(\mathrm{Ob})$ subjects $(n=124)$ showed that the nutritional dietary quality of nut consumers (reporting to eat $42 \mathrm{~g}$ hazelnuts/day for 12 weeks) was remarkably higher than among other groups consuming chocolate, potato crisps or no additional foods [19]. Moreover, including nuts in energy-restricted diets reduced attrition and increased weight loss, indicating that nuts enhance palatability and compliance with diets without compromising health [20].

Several studies have examined the associations of whole fruit or $100 \%$ fruit juice [21] with nutritional or health outcomes such as T2D but there is a lack of studies examining potential links between DF and diet quality. A prospective study conducted in adult participants $(n=13,292)$ in the 1999-2004 National Health and Nutrition Examination Survey (NHANES) demonstrated an association between DF consumption and diet quality [22]. DF consumption was associated with improved nutrient intakes, a higher overall diet quality score, and lower body weight (BW)/adiposity measures [22]. Moreover, in a cross-sectional study in healthy adults $(n=797)$ from Hong Kong, an inverse association has been found between the intake of vegetables, legumes, fruits, dried fruits and Vitamin $C$ and the prevalence of metabolic disorders such as non-alcoholic fatty liver disease (NAFLD) [23].

The 2015 Dietary Guidelines for Americans included the following three healthy dietary patterns: a Healthy US-style Pattern, a Healthy Vegetarian Pattern and a Healthy Mediterranean-style pattern. Fruits, nuts, and seeds play a prominent role in all three of these food-based dietary patterns, which recommend $350-440 \mathrm{~g} /$ day of fruit, and 16-28 g/day of nuts and seeds [24].

\section{In Vivo and In Vitro Studies}

Even though much of the research on nuts, dried fruits and T2D is based on observational studies and human trials, some in vitro and in vivo studies also evaluate their modulatory effect on glucose and insulin metabolism. In this regard, the effect of nuts on glucose and insulin metabolism has been investigated by evaluating nut extracts $[25,26]$ or nuts as a whole [27-29] mainly in mice or rats. However, dried fruit has been investigated-like their non-dried counterparts-mainly in in vitro studies [30-33]. Almost all the research has focused on the extracts from non-edible parts, such as the shell [34], leaves [35,36], stems [37] and roots [38], and very little on the nut or fruit kernel [27-29,39]. However, this review focuses on those studies evaluating specific nutrients (e.g., polyphenols) or edible parts in both traditional nuts and dried fruits with outcomes related to glucose metabolism, IR, and the T2D oxidation/inflammation axis [32,40].

\subsection{Nuts}

The in vivo studies on nuts and T2D-related parameters are summarized in Table 3. These studies were mainly performed using extracts from peanuts or walnuts. Peanut oil supplementation for 42 days in diabetes-induced rats significantly reduced glucose and glycated hemoglobin $\left(\mathrm{HbA}_{1 \mathrm{c}}\right)$ concentrations and improved lipid metabolism compared to normal rats [27]. Other researchers have found similar improvements in glycaemia in genotypes of diabetes in rats fed with peanut oil extract $[41,42]$ or peanut aqueous extract [25]. In the case of walnuts, a polyphenol-rich walnut extract (PWE) for 4 weeks significantly decreased urinary 8-hydroxy-2'-deoxyguanosin levels (an in vivo marker of oxidative stress) and improved serum TG in $d b / d b$ mice [26]. Moreover, an HFD with a 21.5\% of energy from walnuts tested in mice for 20 weeks significantly reduced TG compared to nut-free HFD and tended to improve glucose and IR [29]. 
Table 3. Summary of in vivo studies and their characteristics in the context of nut consumption and type 2 diabetes (T2D)-related outcomes.

\begin{tabular}{|c|c|c|c|c|c|c|}
\hline $\begin{array}{l}\text { First Author (Year) } \\
\text { [Reference] }\end{array}$ & Nut (Study Length) & Animal Model Used & Control & Intervention & $\begin{array}{l}\text { Glucose and Insulin } \\
\text { Metabolism Effects }\end{array}$ & Other Outcomes \\
\hline $\begin{array}{l}\text { Bilbis, L.S.; et al. } \\
\quad \text { (2002) [25] }\end{array}$ & $\begin{array}{l}\text { Aqueous extract of } \\
\text { peanut (21 days) }\end{array}$ & $\begin{array}{l}\text { Alloxan-induced diabetic } \\
\text { rats }(n=12) \text { and } \\
\text { non-diabetic rats }(n=12), \\
\text { divided into } \\
3 \text { equal groups }\end{array}$ & $\begin{array}{l}\text { Non-diabetic with } \\
\text { unrestricted standard diet } \\
\text { and: (a) water ad libitum; } \\
\text { (b) unrestricted access to } \\
\text { drinking water and } 2 \mathrm{~mL} \text { of } \\
\text { the extract } 3 \text { times / day; or } \\
\text { (c) free access to the extract } \\
\text { as the only drinking water. }\end{array}$ & $\begin{array}{l}\text { Diabetic controls: treated as } \\
\text { (a), (b) or (c) }\end{array}$ & $\begin{array}{l}\text { The extract (alone or plus } \\
\text { water) decreased FBG in both } \\
\text { normal and alloxan-induced } \\
\text { diabetic rats. }\end{array}$ & $\begin{array}{l}\text { Significant decrease in serum } \\
\text { TG, TC, HDL-C and LDL-C } \\
\text { in both normal and } \\
\text { alloxan-induced diabetic rats. }\end{array}$ \\
\hline $\begin{array}{l}\text { Fukuda, T.; et al. } \\
\text { (2004) [26] }\end{array}$ & $\begin{array}{c}\text { Polyphenol-rich } \\
\text { walnut extract (PWE) } \\
\text { (4 weeks) }\end{array}$ & $\begin{array}{l}d b / d b(n=15) \text { and } \\
\text { C57BL/KsJ- } d b / d b \\
(n=6) \text { mice }\end{array}$ & $\begin{array}{l}\text { Control } d b / d b \text { mice }(n=8) \\
\text { and C57BL/KsJ-db/ }+\mathrm{m} \\
\text { mice }(n=6, \text { used for the } \\
\text { blank group) were } \\
\text { given water. }\end{array}$ & $\begin{array}{l}\text { Experimental } d b / d b \text { mice } \\
(n=7) \text { received oral PWE } \\
(200 \mathrm{mg} / \mathrm{kg} \text { BW })\end{array}$ & $\begin{array}{l}\text { Significant decrease in the } \\
\text { level of urinary } \\
\text { 8-hydroxy-2'-deoxyguanosin } \\
\text { (in vivo marker of oxidative } \\
\text { stress) in PWE-fed mice }\end{array}$ & $\begin{array}{l}\text { Serum TG level was } \\
\text { improved after PWE } \\
\text { administration }\end{array}$ \\
\hline $\begin{array}{l}\text { Ramesh, B.; et al. } \\
\quad \text { (2006) [27] }\end{array}$ & Peanut oil (42 days) & $\begin{array}{l}\text { Normal }(n=12) \text { and } \\
\text { STZ-diabetes induced } \\
(n=18) \text { Wistar rats }\end{array}$ & $\begin{array}{l}\text { G1: Normal rats G3: } \\
\text { Diabetic rats }\end{array}$ & $\begin{array}{l}\text { G2: Normal rats + peanut } \\
\text { oil diet }(2 \%) \text { G4: Diabetic } \\
\text { rats + peanut oil diet }(2 \%) \\
\text { G5: Diabetic rats + GLI } \\
(600 \mu \mathrm{g} / \mathrm{kg} \mathrm{BW})\end{array}$ & $\begin{array}{l}\text { Diabetic rats fed with peanut } \\
\text { oil significantly reduce } \\
\text { glucose, } \mathrm{HbA}_{1 \mathrm{C}} \text {, and G6Pase } \\
\text { and FBP activities }\end{array}$ & $\begin{array}{l}\text { Diabetic rats fed with peanut } \\
\text { oil showed a small but } \\
\text { significant reduction in TC, } \\
\text { VLDL-C, LDL-C and TG and } \\
\text { an increase in HDL-C. }\end{array}$ \\
\hline $\begin{array}{l}\text { Vassiliou, E.K.; et al. } \\
\text { (2009) [41] }\end{array}$ & Peanut oil (21 days) & Male KKAy $(n=24)$ mice & $\begin{array}{l}\text { KKA }{ }^{y} \text { mice fed with } \\
\text { normal diet ( } 11.4 \% \text { fat) }\end{array}$ & $\begin{array}{l}\text { Diabetic KKAy + HFD. } \\
\text { Diabetic KKA }+ \text { HFD with } \\
\text { peanut oil }(0.70 \mathrm{~mL} / \text { day }) \text {. } \\
\text { HFD is } 58 \% \text { fat. }\end{array}$ & $\begin{array}{l}\text { Diabetic mice administered } \\
\text { peanut oil had lower glucose } \\
\text { levels than animals } \\
\text { administered HFD alone. }\end{array}$ & \\
\hline $\begin{array}{l}\text { Choi, Y.; et al. } \\
\text { (2016) [29] }\end{array}$ & Walnuts (20 weeks) & $\begin{array}{l}\text { Male C57BL/6J mice } \\
\text { ( } \geq 6 \text { mice/group) }\end{array}$ & Regular rodent chow & $\begin{array}{l}\text { HFD ( } 45 \% \text { energy-derived) } \\
\text { with or without walnuts } \\
\text { ( } 21.5 \% \text { energy-derived) }\end{array}$ & $\begin{array}{l}\text { Glucose and insulin } \\
\text { resistance tended to improve } \\
\text { with walnut } \\
\text { supplementation. }\end{array}$ & $\begin{array}{l}\text { Walnut supplementation did } \\
\text { not change the HFD-induced } \\
\text { increase in BW or VFM. } \\
\text { However, dietary walnuts } \\
\text { significantly decreased the } \\
\text { amounts of hepatic TG } \\
\text { observed in HFD-fed mice. }\end{array}$ \\
\hline $\begin{array}{l}\text { Adewale, O.F.; et al. } \\
\text { (2016) [42] }\end{array}$ & $\begin{array}{l}\text { Peanut oil Palm oil } \\
\quad \text { ( } 3 \text { weeks) }\end{array}$ & $\begin{array}{l}\text { Normal }(n=12) \text { and } \\
\text { alloxan-induced diabetic } \\
\text { Wistar rats }(n=36)\end{array}$ & Non-diabetic & $\begin{array}{l}\text { Diabetic } \\
\text { non-supplemented. } \\
\text { Diabetic supplemented } \\
\text { with } \mathrm{PeO} \text { or } \mathrm{PaO} \\
(200 \mathrm{mg} / \mathrm{kg} / \text { day })\end{array}$ & $\begin{array}{l}\text { Significant reduction in blood } \\
\text { glucose of supplemented } \\
\text { groups }(\mathrm{PeO}+\mathrm{PaO}) \\
\text { compared to the diabetic } \\
\text { non-supplemented group. }\end{array}$ & $\begin{array}{l}\text { Plasma Vitamins } C \text { and } E \text { and } \\
\text { albumin levels were } \\
\text { significantly increased in the } \\
\text { supplemented groups versus } \\
\text { the diabetic } \\
\text { non-supplemented group. }\end{array}$ \\
\hline
\end{tabular}

BW, body weight; FBG, fasting blood glucose; FBP, fructose-1,6-bisphosphatase; G6Pase, glucose 6-phosphatase; GLI, glibenclamide; HDL-C, high-density lipoprotein cholesterol; HFD, high-fat diet; LDL-C, low-density lipoprotein cholesterol; PaO, palm oil; PeO, peanut oil; PWE, polyphenol-rich walnut extract; STZ, streptozotocin; T2D, type 2 diabetes; TC, total cholesterol; TF, tissue factor; TG, triglycerides; VFM, visceral fat mass; VLDL-C, very low-density lipoprotein. 
In vitro assessment of the T2D-related antioxidant and inflammatory capacity of nuts has largely been conducted by examining the ability of extracts to increase the resistance of human plasma or low density lipoprotein (LDL) to oxidation. Extracts of walnut [43], almond and almond skins [44,45], pistachio [46], and hazelnut [47] have been found to increase the lag time oxidation of LDL. However, little research has focused on their in vitro effects on glucose and insulin metabolism. Specifically, a hydro-ethanolic extract of cashew nut and its principal compound, anacardic acid, significantly stimulated glucose uptake in $\mathrm{C} 2 \mathrm{C} 12$ muscle cells in a concentration-dependent manner, suggesting that it may be a potential anti-diabetic nutraceutical [48]. Moreover, cytoprotective activity of pistachio extracts (methanolic, water or ethyl acetate) against oxidative (reactive oxygen species formation) and carbonyl stress has also been reported in a T2D model in hepatocytes from rats [49].

\subsection{Dried Fruits}

Both in vitro and in vivo research has mostly focused on grape. Overman and collaborators showed that a grape powder extract (GPE) significantly attenuated lipopolysaccharide (LPS)-mediated inflammation in macrophages and decreased the capacity of LPS-stimulated human macrophages to inflame adipocytes and cause IR [30]. Moreover, GPE further attenuated tumor necrosis factor- $\alpha$ $(\mathrm{TNF}-\alpha)$ mediated inflammation and IR in primary cultures of human adipocytes [31]. Grape polyphenol extract modulated in vitro membrane phospholipid fatty acid (FA) composition but also decreased muscle TG content and increased muscle glucose transporter type 4 (GLUT4) expression in high-fat-high-sucrose diet-fed rats. Overall, it improved insulin resistance status (i.e., HOMA-IR parameter) [50]. This is of considerable importance because the accumulation of muscle TG content and the modification of the muscle phospholipid fatty acid pattern may have an impact on lipid metabolism and increase the risk of developing T2D [51]. Mice fed with grape skin extract showed hypoglycaemic and anti-hyperglycaemic effects (independent of an increase in insulin release) but are probably dependent on an increase in insulin sensitivity resulting from the activation of the insulin-signaling cascade in skeletal muscle [52]. Furthermore, grape seed aqueous extract protected the pancreas against oxidative stress, inflammation and apoptosis-induced damage while preserving pancreatic function at near normal levels in diabetic rats [53].

Other DF extracts have also been evaluated. Treatment with a date fruit extract was effective at decreasing behavioral, neurophysiological, and pathological alterations induced by diabetes in the peripheral nerves of streptozotocin (STZ)-induced diabetic rats (well-characterized animal model of type 1 diabetes) [33]. Moreover, daily consumption of a low- or high-fat diet supplemented with $1 \%$ black currant powder extract (with $32 \%$ of anthocyanins) for 8 weeks reduced body weight gain and improved glucose metabolism [54].

The beneficial effect of fruit juices and fermented grape juice (i.e., wine) have also been an important focus of research. Schmatz and collaborators investigated the ex vivo effects of a moderate consumption of red wine (RW) and grape juice (GJ), and the in vitro effects of various substances (resveratrol, caffeic acid, gallic acid, quercetin and rutin) on STZ-induced diabetic rats. They demonstrated decreased platelet aggregation in diabetic-induced rats after moderate RW and GJ consumption for 45 days [55]. Similarly, resveratrol increased the hydrolysis of adenosine triphosphate (ATP), while quercetin decreased it in platelets [55]. These results were extended using a wine grape powder supplementation, which prevented hyperglycemia and IR, and reduced oxidative stress in a rat model of metabolic syndrome (MetS) [56].

Specific compounds found in both nuts and DFs were also further investigated. Quercetin and trans-resveratrol are plant polyphenols which have showed a significant reduction of IR and inflammation associated with obesity. Eid et al. showed that quercetin (isolated from lingonberry) exerted an anti-diabetic activity by stimulating adenosine monophosphate-activated protein kinase (AMPK) [40]. Moreover, quercetin also enhanced basal glucose uptake in mouse myoblast C2C12 muscle cells in the absence of insulin [40] via a mechanism which is highly analogous to metformin. 
Importantly, quercetin seems to be as effective as or more effective than resveratrol in attenuating TNF- $\alpha$-mediated inflammation and IR in primary human adipocytes and macrophages [32,57].

\section{Epidemiological Studies on Nuts}

The relationship between the consumption of different food categories and the incidence or prevalence of metabolic disorders has been explored all over the world. As is shown in Table 4, numerous epidemiological studies have assessed the associations between nut consumption and T2D. However, no studies have been published on the link between DF consumption and risk of T2D.

As far as nuts are concerned, several studies have found an inverse association between the frequency of consumption and the development of this metabolic pathology [58-64]. In the Nurses' Health Study (NHS) and NHS II cohort, the intake of different types of nut was explored [61,64]. Total nut, walnut and peanut butter intake were associated with a lower risk of T2D in women. In the NHS ( $n=83,818$ female subjects), those with the highest nut consumption ( $28 \mathrm{~g} / \mathrm{day} ; \geq 5$ days a week) had a lower relative risk (RR) of developing T2D (0.73 [95\% confidence interval (CI), 0.60-0.89]) than those who never/almost never consume $(0.92$ [95\% CI, 0.85-1.00]) [61]. Results were similar for peanut butter: the RR was 0.79 (95\% CI, 0.68-0.91) in those women who had a higher intake (5 times or more a week) than those who never/almost never ate peanut butter [61]. After combining NHS and NHS II cohorts, in a total of 137,953 female subjects, Pan and collaborators found that walnut consumption was inversely associated with risk of T2D [64].

These results are in line with those of a cross-sectional study of 7,210 subjects at high CV risk within the context of the PREvención con DIeta MEDiterránea (PREDIMED) study, where the upper category of nut consumption had a lower prevalence of T2D than the lower category [63]. A recent prospective study also associated the consumption of nuts-higher than 4 times a week-with a lower risk of T2D [60]. A cross-sectional study performed in the context of the National Health and Nutrition Examination Survey (NHANES) established a relation between the homeostatic model assessment of insulin resistance (HOMA-IR) and tree nut consumption. Decreased insulin resistance and lower levels of $\beta$-cell function markers were found in the nut consumers than the non-consumers [59]. In a large cohort of the Netherlands Cohort Study (NLCS), the total nut intake was associated to lower T2D cause-specific mortality in men and women [65].

Even though current evidence shows that nuts have a strong protective effect against the progress of T2D, especially in women, some epidemiological studies have not identified this relation [66,67]. The latest systematic review and meta-analysis designed to assess the relation between nut consumption and risk of cancer and T2D was published in 2015. It included five studies that were linked to T2D. After pooling data from studies conducted in both genders, it was found that there was no statistically significant association between nut consumption and risk of developing T2D (RR $=0.98$ [95\% CI, 0.84-1.14]), even though the heterogeneity was significant [68]. 
Table 4. Summary of epidemiological studies evaluating nut consumption.

\begin{tabular}{|c|c|c|c|c|c|}
\hline $\begin{array}{l}\text { First Author (Year) } \\
\text { [Reference] }\end{array}$ & $\begin{array}{l}\text { Study Name } \\
\text { (Design) }\end{array}$ & Number of Subjects & Years of Follow-Up & Exposure & Findings \\
\hline $\begin{array}{l}\text { Jiang, R.; et al. } \\
\text { (2002) [61] }\end{array}$ & $\begin{array}{c}\text { NHS } \\
\text { (Prospective) }\end{array}$ & 83,818 women & 16 & $\begin{array}{l}\geq 5 \text { times/week vs. } \\
\text { never/almost never }\end{array}$ & $\begin{array}{l}\text { Nut and peanut butter consumption was inversely } \\
\text { associated with the risk of incident T2D. }\end{array}$ \\
\hline $\begin{array}{l}\text { Nettleton, J.A.; et al. } \\
\text { (2008) [58] }\end{array}$ & $\begin{array}{c}\text { MESA } \\
\text { (Prospective) }\end{array}$ & 5011 men and women & 5 & $\begin{array}{l}\text { Quintiles of low-risk food } \\
\text { pattern }\end{array}$ & $\begin{array}{l}\text { High intake of whole grains, fruit, nuts/seeds, } \\
\text { and green leafy vegetables was inversely } \\
\text { associated to the risk of incident T2D. }\end{array}$ \\
\hline $\begin{array}{l}\text { Villegas, R.; et al. } \\
\quad \text { (2008) [62] }\end{array}$ & $\begin{array}{c}\text { SWHS } \\
\text { (Prospective) }\end{array}$ & 64,227 women & 4.6 & $\begin{array}{l}\text { Quintiles of peanut } \\
\text { consumption }\end{array}$ & $\begin{array}{l}\text { Consumption of peanuts was associated with a } \\
\text { decreased risk of incident T2D. }\end{array}$ \\
\hline $\begin{array}{l}\text { Kochar, J.; et al. } \\
\text { (2010) [67] }\end{array}$ & $\begin{array}{c}\text { PHS I } \\
\text { (Prospective) }\end{array}$ & 20,224 men & 19.2 & $\begin{array}{l}\geq 7 \text { servings of nuts/week vs. } \\
\text { rarely or never consumers }\end{array}$ & $\begin{array}{l}\text { No statistically significant association was found } \\
\text { between nut consumption and T2D in either lean } \\
\text { or overweight/obese subjects. }\end{array}$ \\
\hline $\begin{array}{l}\text { Ibarrola-Jurado, N.; } \\
\text { et al. (2013) [63] }\end{array}$ & $\begin{array}{c}\text { PREDIMED } \\
\text { (Cross-sectional) }\end{array}$ & $\begin{array}{l}7210 \text { at high } \\
\text { cardiovascular risk }\end{array}$ & Baseline & $\begin{array}{l}<1 \text { serving/week, } \\
1-3 \text { servings/week and } \\
>3 \text { servings/week }\end{array}$ & $\begin{array}{l}\text { The upper category of nut consumption had a } \\
\text { lower prevalence of T2D than the lowest category. }\end{array}$ \\
\hline $\begin{array}{l}\text { Pan, A.; et al. } \\
\text { (2013) [64] }\end{array}$ & $\begin{array}{l}\text { NHS, NHS II } \\
\text { (Prospective) }\end{array}$ & 137,953 women & 10 & $\begin{array}{l}1-3 \text { servings/month, } \\
1 \text { serving/week, } \\
\text { and } \geq 2 \text { servings/week of } \\
\text { walnuts vs. never/rarely }\end{array}$ & $\begin{array}{l}\text { Higher walnut consumption is associated with a } \\
\text { significantly lower risk of T2D incidence. }\end{array}$ \\
\hline $\begin{array}{l}\text { O'Neil, C.E.; et al. } \\
\text { (2015) [59] }\end{array}$ & $\begin{array}{c}\text { NHANES } \\
\text { (Cross-sectional) }\end{array}$ & 14,386 men and women & 6 & $\begin{array}{l}\text { Tree nut consumption } \\
\text { compared with no } \\
\text { consumption }\end{array}$ & $\begin{array}{l}\text { Tree nut consumption was associated with lower } \\
\text { HOMA-IR }\end{array}$ \\
\hline $\begin{array}{l}\text { Buijsse, B.; et al. } \\
\text { (2015) [66] }\end{array}$ & $\begin{array}{l}\text { EPIC-InterAct } \\
\text { Study } \\
\text { (Case-cohort) }\end{array}$ & 16,154 men and women & $\begin{array}{l}\text { 12.3 Incident cases } \\
\text { of T2D at } 6.8\end{array}$ & $\begin{array}{l}\text { Non-consumers vs. the } \\
\text { middle tertile of } \\
\text { consumption. }\end{array}$ & $\begin{array}{l}\text { Consumption of nuts and seeds does not modify } \\
\text { T2D risk under isocaloric conditions and } \\
\text { independent from BMI. }\end{array}$ \\
\hline $\begin{array}{l}\text { Asghari, G.; et al. } \\
\text { (2017) [60] }\end{array}$ & $\begin{array}{c}\text { TLGS } \\
\text { (prospective) }\end{array}$ & 1984 men and women & $6.2 \pm 0.7$ & $\begin{array}{l}\geq 4 \text { servings/week vs. } 1 \text { or } \\
<1 \text { serving/week }\end{array}$ & $\begin{array}{l}\text { Nut consumption was associated with a lower risk } \\
\text { of T2D incidence. }\end{array}$ \\
\hline
\end{tabular}




\section{Human Clinical Trials}

The effect of nut consumption on glucose and insulin metabolism has also been researched in acute and chronic clinical trials. Acute studies mostly demonstrate a decrease in postprandial glycaemia and hyperinsulinemia after nut consumption. In contrast, chronic randomized clinical trials designed to analyze the effects on glucose metabolism provided controversial results.

\subsection{Nuts}

\subsubsection{Acute Clinical Trials on Nuts}

Table 5 summarizes various acute clinical studies of nut consumption, most of which focus on almonds [69-73]. In a randomized crossover trial in healthy subjects, almond intake decreased postprandial glycaemia and insulinaemia [69]. In a dose-response study conducted in healthy individuals, almond intake attenuated the postprandial glycaemic response of white bread [70]. In impaired glucose-tolerant subjects, it was observed that the consumption of almonds with a meal also decreased blood glucose in plasma [71]. In a recent crossover study performed in pre-diabetic subjects, a preload of almonds decreased postprandial glycaemia [73]. In healthy and diabetic individuals, Cohen et al. also showed a 30\% reduction in postprandial glycaemia after almond consumption compared with a starchy meal [72].

The effect of pistachio intake on postprandial glycaemia was investigated by Kendall et al. in two randomized studies. In overweight $(\mathrm{Ow})$ healthy subjects, pistachio consumption was reported to have a minimal effect on postprandial glycaemia. When pistachios were included in a carbohydrate meal, the relative glycaemic response (RGR) was attenuated [74]. In a crossover trial with 20 subjects with MetS, postprandial glycaemia decreased after the consumption of pistachios $(85 \mathrm{~g})$ compared to white bread. In the same study, a peripheral increase in the glucagon-like peptide-1 (GLP-1) concentrations was also observed after pistachio consumption compared with the consumption of white bread [75].

For peanuts, a randomized crossover trial conducted in 13 healthy subjects reported a decreased postprandial glycaemic response after the consumption of a breakfast containing $63 \mathrm{~g}$ of one of the following types of peanuts: raw with skin, roasted without skin and ground-roasted without skin [76]. Similarly, in a parallel study conducted in 65 overweight and obese men, peanut consumption reduced postprandial insulinaemia levels compared to high-oleic peanut consumption [77].

Nut consumption was observed to have similar beneficial effects on glucose and insulin metabolism in the only study to analyze the effect of a mix of nuts (almonds, macadamias, walnuts, pistachios, hazelnuts and pecans). In this study conducted in 10 diabetic and 14 non-diabetic subjects, nut consumption decreased the RGR compared to white bread. Importantly, this study also reported that nut consumption improved short-term glycaemic control in patients with T2D [74].

In summary, nuts seem to have beneficial postprandial glycaemic effects when consumed alone or in combination with high carbohydrate foods, and so may potentially help to prevent and manage impaired glucose states. 
Table 5. Summary of acute clinical studies analyzing the effect of nut consumption on postprandial response.

\begin{tabular}{|c|c|c|c|c|c|c|}
\hline $\begin{array}{l}\text { First Author (Year) } \\
\text { [Reference] }\end{array}$ & $\begin{array}{c}\mathrm{N}^{\circ} \text { of Subjects }(\mathrm{M} / \mathrm{F}) \\
\text { Type of Subject } \\
\text { (Age in Years) }\end{array}$ & $\begin{array}{l}\text { Type of Nut } \\
\text { (Study Design) }\end{array}$ & Control Group & Intervention Group & $\begin{array}{l}\text { Glucose and Insulin } \\
\text { Metabolism Outcomes }\end{array}$ & Other Outcomes \\
\hline $\begin{array}{l}\text { Jenkins, D.J.; et al. } \\
\text { (2006) [69] }\end{array}$ & $\begin{array}{c}15(7 / 8) \text { Healthy } \\
\text { subjects }(26.3 \pm 8.6)\end{array}$ & Almonds (crossover) & $97 \mathrm{~g}$ of white bread & $\begin{array}{l}\text { - } \quad \text { Almond meal: } 60 \mathrm{~g} \text { almonds }+97 \mathrm{~g} \text { bread } \\
\text { - Parboiled rice meal: } 68 \mathrm{~g} \text { cheese and } \\
14 \mathrm{~g} \text { butter }+60 \mathrm{~g} \text { parboiled rice } \\
\text { Mashed potato meal: } 62 \mathrm{~g} \text { cheese and } \\
16 \mathrm{~g} \text { butter }+68 \mathrm{~g} \text { mashed potatoes }\end{array}$ & $\begin{array}{l}\text { Almonds decrease postprandial } \\
\text { glycaemia and insulinaemia. }\end{array}$ & $\begin{array}{l}\text { Almonds are likely to decrease } \\
\text { oxidative damage to serum } \\
\text { proteins by decreasing } \\
\text { glycaemic excursion and } \\
\text { providing antioxidants. }\end{array}$ \\
\hline $\begin{array}{l}\text { Josse, A.R.; et al. } \\
\text { (2007) [70] }\end{array}$ & $\begin{array}{c}9(7 / 2) \text { Healthy } \\
\text { subjects }(27.8 \pm 6.9)\end{array}$ & $\begin{array}{l}\text { Almonds (crossover } \\
\text { dose-response study) }\end{array}$ & White bread & $\begin{array}{ll}\text { - } & \text { White bread }+30 \mathrm{~g} \text { almonds } \\
\text { - } & \text { White bread }+60 \mathrm{~g} \text { almonds } \\
\text { - } & \text { White bread }+90 \mathrm{~g} \text { almonds }\end{array}$ & $\begin{array}{l}\text { The 90-g almond meal resulted } \\
\text { in a significantly lower GI than } \\
\text { the white bread control meal }\end{array}$ & \\
\hline $\begin{array}{l}\text { Mori, A.M.; et al. } \\
\quad \text { (2011) [71] }\end{array}$ & $\begin{array}{l}14(8 / 6) \text { IGT } \\
(39.3 \pm 10.9)\end{array}$ & Almonds (crossover) & $\begin{array}{l}75 \mathrm{~g} \text { of available } \mathrm{CHO} \\
\text { (No almonds) }\end{array}$ & $\begin{array}{ll}75 \mathrm{~g} \text { of available } \mathrm{CHO} \text { from: } \\
- & \text { Whole almonds } \\
- & \text { Almond butter } \\
- & \text { Defatted almond flour } \\
- & \text { Almond oil }\end{array}$ & $\begin{array}{l}\text { Whole almonds significantly } \\
\text { attenuated second-meal and } \\
\text { daylong blood glucose IAUC. }\end{array}$ & $\begin{array}{l}\text { GLP-1 concentrations did not } \\
\text { significantly vary between } \\
\text { treatments. }\end{array}$ \\
\hline $\begin{array}{l}\text { Kendall, C.W.; et al. } \\
\text { (2011) [74] }\end{array}$ & $\begin{array}{l}10(3 / 7) \text { Ow healthy } \\
\text { subjects }(48.3 \pm 6.4)\end{array}$ & Pistachios (crossover) & White bread & $\begin{array}{l}\text { Study 1: } \\
-\quad 28,56 \text { and } 84 \mathrm{~g} \text { pistachios } \\
-\quad 28,56 \text { and } 84 \mathrm{~g} \\
\text { Study 2: } \\
-\quad 56 \mathrm{~g} \text { of pistachios + different commonly } \\
\quad \text { consumed carbohydrate foods } \\
\quad \text { (50 g available carbohydrate). }\end{array}$ & $\begin{array}{l}\text { Pistachios consumed alone had a } \\
\text { minimal effect on postprandial } \\
\text { glycaemia. Pistachios consumed } \\
\text { with a carbohydrate meal } \\
\text { attenuated the RGR. }\end{array}$ & \\
\hline $\begin{array}{l}\text { Cohen, A.E. and } \\
\text { Johnston, C.S. } \\
\text { (2011) [72] }\end{array}$ & $\begin{array}{l}20(6 / 14) \text { Healthy } \\
\text { subjects }(n=13) \text { and } \\
\text { T2D subjects }(n=7) \\
\text { (Healthy: } 53.0 \pm 3 \\
\text { and T2D: } 66.0 \pm 3.3)\end{array}$ & $\begin{array}{l}\text { Almonds (postprandial: } \\
\text { crossover trial) }\end{array}$ & No almond meal & $28 \mathrm{~g}$ almonds enriched meal & $\begin{array}{l}\text { The ingestion of almonds } \\
\text { immediately before a starchy } \\
\text { meal significantly reduced } \\
\text { postprandial glycaemia by } 30 \% \text {. }\end{array}$ & \\
\hline $\begin{array}{l}\text { Kendall, C.W.; et al. } \\
\text { (2011) [78] }\end{array}$ & $\begin{array}{l}24(11 / 13) \text { Healthy } \\
(n=14) \text { and T2D } \\
\text { subjects }(n=10) \\
\text { (Healthy: } 36.0 \pm 4 \\
\text { and T2D: } 68.0 \pm 2)\end{array}$ & $\begin{array}{l}\text { Mixed nuts (i.e., almonds, } \\
\text { macadamias, walnuts, } \\
\text { pistachios, hazelnuts and } \\
\text { pecans) (crossover) }\end{array}$ & White bread & 3 doses of 30,60 and $90 \mathrm{~g}$ of mixed nuts & $\begin{array}{l}\text { Nuts improve short-term } \\
\text { glycaemic control in patients } \\
\text { with T2D. }\end{array}$ & \\
\hline
\end{tabular}


Table 5. Cont

\begin{tabular}{|c|c|c|c|c|c|c|}
\hline $\begin{array}{l}\text { First Author (Year) } \\
\text { [Reference] }\end{array}$ & $\begin{array}{c}\mathrm{N}^{\circ} \text { of Subjects }(\mathrm{M} / \mathrm{F} \text { ) } \\
\text { Type of Subject } \\
\text { (Age in Years) }\end{array}$ & $\begin{array}{c}\text { Type of Nut } \\
\text { (Study Design) }\end{array}$ & Control Group & Intervention Group & $\begin{array}{l}\text { Glucose and Insulin } \\
\text { Metabolism Outcomes }\end{array}$ & Other Outcomes \\
\hline $\begin{array}{l}\text { Reis, C.E.; et al. } \\
\text { (2011) [76] }\end{array}$ & $\begin{array}{c}13(4 / 9) \text { Healthy } \\
\text { subjects }(28.5 \pm 10)\end{array}$ & Peanuts (crossover) & Cheese sandwich & $\begin{array}{ll} & 63 \mathrm{~g} \text { of: } \\
- & \text { raw peanuts with skin } \\
- & \text { roasted peanuts without skin } \\
- & \text { ground-roasted peanuts without skin }\end{array}$ & $\begin{array}{l}\text { The ingestion of ground-roasted } \\
\text { peanuts without skin for } \\
\text { breakfast leads to a lower } \mathrm{CHO} \\
\text { intake and reduced postprandial } \\
\text { glycaemic response. }\end{array}$ & \\
\hline $\begin{array}{l}\text { Moreira, A.P.; et al. } \\
\quad \text { (2014) [77] }\end{array}$ & $\begin{array}{l}65 \text { men Ow/Ob } \\
\text { (Range: } 18-50)\end{array}$ & $\begin{array}{l}\text { Conventional peanuts } \\
\text { and high-oleic peanuts } \\
\text { (parallel) }\end{array}$ & $56 \mathrm{~g}$ biscuit & $\begin{array}{ll}- & 56 \mathrm{~g} \text { conventional peanuts }(n=21) \\
- & 56 \mathrm{~g} \text { high-oleic peanuts }(n=23)\end{array}$ & $\begin{array}{l}\text { Conventional peanut } \\
\text { consumption was associated } \\
\text { with decreased postprandial } \\
\text { insulinaemia, which might be } \\
\text { beneficial for saving } \beta \text {-cell } \\
\text { function, independently of the } \\
\text { influence on LPS concentrations. }\end{array}$ & \\
\hline $\begin{array}{l}\text { Kendall, C.W.; et al. } \\
\text { (2014) [75] }\end{array}$ & $\begin{array}{c}20(8 / 12) \text { Subjects } \\
\text { with MetS }(54.0 \pm 8)\end{array}$ & Pistachios (crossover) & $\begin{array}{l}\text { Control 1: white } \\
\text { bread } \\
\text { Control 2: (white } \\
\text { bread + butter + } \\
\text { cheese) }\end{array}$ & $\begin{array}{l}\text { Test meal 1: } \mathrm{WB}+85 \mathrm{~g} \text { of pistachios } \\
\text { Test meal 2: } 85 \mathrm{~g} \text { of pistachios }\end{array}$ & $\begin{array}{l}\text { Pistachio consumption reduced } \\
\text { postprandial glycaemia } \\
\text { compared with white bread. }\end{array}$ & $\begin{array}{l}\text { Pistachio consumption } \\
\text { increased GLP-1 levels } \\
\text { compared with white bread. }\end{array}$ \\
\hline $\begin{array}{l}\text { Crouch, M.A. and } \\
\text { Slater, R.T. (2016) [73] }\end{array}$ & $\begin{array}{l}20(13 / 7) \text { Subjects } \\
\text { with pre-diabetes * } \\
\text { (Mean: 60.8) }\end{array}$ & Almonds (crossover) & No almonds & 12 units of dry-roasted almonds & $\begin{array}{l}\text { A low-calorie almond preload } \\
\text { "appetizer" decreased } \\
\text { postprandial hyperglycemia. }\end{array}$ & \\
\hline
\end{tabular}

Age is shown as mean \pm SD unless otherwise stated. BMI, body mass index; $\mathrm{CHO}$, carbohydrate; GLP-1, glucagon-like peptide-1; $\mathrm{Hb}_{1 c}$, glycated hemoglobin; IAUC, incremental area under the curve; IGT, impaired glucose tolerance; LPS, lipopolysaccharide; MetS, metabolic syndrome; M/F, male/female; Ob, obese; Ow, overweight; RGR, relative glycaemic responses; T2D, type 2 diabetes; WB, white bread. * also include "isolated 1-h glucose $>160 \mathrm{mg} / \mathrm{dL}$ ". 


\subsubsection{Chronic Clinical Trials on Nuts}

Most of the RCTs have compared nut-enriched diets with control diets in order to analyze their effects on lipid profile, and blood glucose and insulin concentrations as a secondary outcome. However, some, mainly conducted in subjects with T2D [72,79-84], but also in pre-diabetic [85], hyperlipemic [86], overweight/obese [87] and healthy individuals [88], were specifically designed to assess changes in glucose or insulin metabolism after nut consumption (Table 6).

In 2002, Lovejoy and coworkers evaluated the effect of an almond-enriched diet in 20 healthy and 30 T2D subjects in two different studies [79]. Healthy subjects, supplemented with $100 \mathrm{~g}$ almonds/day for 4 weeks and advised to reduce their energy intake by an equivalent amount, did not change their insulin sensitivity, whereas their body weight increased and their lipid profile improved. In a second study, subjects with T2D were randomized following a crossover design to one of 4 diets with different fat contents $(25 \%$ or $37 \%$ ) with $10 \%$ of fat from almonds or from olive or canola oil, with a minimum washout of 2 weeks between periods. Fat source (almond vs. oil) or fat level (high fat vs. low fat) were not observed to have any significant effect on either the glucose or insulin index. In contrast, in a crossover study conducted in 20 Chinese patients with T2D and mild-hyperlipidemia assigned to either a control diet (National Cholesterol Education Program (NCEP) step II diet) or an almond-enriched diet (with almonds replacing the $20 \%$ total daily calorie intake) for 4 weeks, a significant decrease in fasting insulin and glucose concentrations together with an improvement of HOMA-IR were reported during the almond phase [80]. In a similar crossover study conducted in 48 diabetic patients who received $50 \mathrm{~g} /$ day of pistachios and a pistachio-free diet (12 weeks each period), with an 8-week washout, a significant improvement in fasting blood glucose (FBG) and $\mathrm{HbA}_{1 c}$ was observed during the pistachio consumption, while no changes in HOMA-IR were reported [83]. Recently, Gulati and coworkers conducted a pre-post intervention study in a group of 50 Asian Indians who consumed 20\% of total energy in the form of whole raw almonds for 24 weeks preceded by a control diet free of nuts. Although no changes in FBG were observed during the almond consumption, the authors found a significant reduction in glycosylated hemoglobin, together with an improvement in other T2D risk factors such as waist circumference or inflammation status [84]. To determine whether the beneficial effect of nut consumption on glucose and insulin metabolism could also be extended to pre-diabetic subjects our group conducted a randomized crossover study in 54 pre-diabetic subjects who consumed a pistachio-supplemented diet (55 g pistachio/day) and a control diet (nut-free diet), each for 4 months with a 2-week washout period. We found a beneficial effect of pistachio intake on fasting glucose, insulin, and HOMA-IR. Other cardiometabolic risk markers such as fibrinogen, oxidized LDL, platelet factor 4 and GLP-1 were also modified appropriately during the consumption of pistachios [85].

Changes in fasting glucose or insulin levels, HOMA-IR and glycosylated hemoglobin have also been assessed as secondary outcomes in several clinical feeding trials with different designs (parallel, crossover) and subject characteristics (i.e., healthy, overweight/obese, TD2, MetS), mainly using walnuts and almonds, and with different intervention lengths (from 2 weeks to 2 years). The results obtained are controversial. Although most studies found no improvement in glucose/insulin metabolism [89-103], others reported a significant reduction in FBG levels [89,92,104,105], fasting insulin or insulin resistance $[90,92,106,107]$ and $\mathrm{HbA}_{1 \mathrm{c}}$ [92]. However, a meta-analysis of RCTs including 25 trials with a total of 1,650 particpants who were otherwise healthy or had dyslipidaemia, metabolic syndrome or type 2 diabetes mellitus showed that the consumption of tree nuts led to modest decreases in fasting blood glucose compared with control diet interventions [108]. 
Table 6. Summary of chronic clinical trials and their characteristics in the context of nut consumption.

\begin{tabular}{|c|c|c|c|c|c|c|}
\hline $\begin{array}{l}\text { First Author (Year) } \\
\text { [Reference] }\end{array}$ & $\begin{array}{c}\mathrm{N}^{\circ} \text { of Subjects }(\mathrm{M} / \mathrm{F}) \\
\text { Type of Subjects } \\
\text { (Age in Years) }\end{array}$ & $\begin{array}{l}\text { Nut Study Design } \\
\text { (Length of the } \\
\text { Intervention) }\end{array}$ & Control Group & Intervention Group(s) & $\begin{array}{c}\text { Glucose and Insulin Metabolism } \\
\text { Outcomes }\end{array}$ & Other Outcomes \\
\hline $\begin{array}{l}\text { Lovejoy, J.C.; et al. } \\
\quad(2002)[79]\end{array}$ & $\begin{array}{c}30(13 / 17) \\
\text { T2D subjects } \\
(\text { mean } \pm \text { SEM: } \\
53.8 \pm 1.9)\end{array}$ & $\begin{array}{l}\text { Almonds } \\
\text { Crossover }(1 \mathrm{month} \\
\text { per period) }\end{array}$ & $\begin{array}{l}\text { HF-Control } \\
\text { LF-Control }\end{array}$ & $\begin{array}{l}\text { HF-HA } \\
\text { LF-HA }\end{array}$ & $\begin{array}{l}\text { No significant changes in glycaemia } \\
\text { were observed. }\end{array}$ & $\begin{array}{l}\text { Total cholesterol was lowest after the } \\
\text { HF-HA diet. HDL-C was significantly } \\
\text { decreased after the almond diet; } \\
\text { however, no significant effect of fat } \\
\text { source on LDL: HDL was reported. }\end{array}$ \\
\hline $\begin{array}{c}\text { Jenkins, D.J.A.; et al. } \\
\text { (2008) [86] }\end{array}$ & $\begin{array}{l}27(15 / 12) \\
\text { Hyperlipidemic } \\
\text { subjects } \\
(64 \pm 9)\end{array}$ & $\begin{array}{l}\text { Almonds } \\
\text { Crossover }(1 \mathrm{month} \\
\text { per period) }\end{array}$ & $147 \pm 6 \mathrm{~g} /$ day of muffins & $\begin{array}{l}\text { Almonds }(73 \pm 3 \mathrm{~g} / \text { day) } \\
\text { Half portion of almonds } \\
(37 \pm 2 \mathrm{~g} / \text { day) plus } \\
\text { muffins }(75 \pm 3 \mathrm{~g} / \text { day) } \\
\text { Isoenergetic (mean, } \\
423 \mathrm{Kcal} / \text { day) }\end{array}$ & $\begin{array}{l}\text { No significant changes were observed in } \\
\text { FBG, insulin, C-peptide, or HOMA-IR. } \\
\text { The 24-h urinary C-peptide output, as a } \\
\text { marker of } 24-h \text { insulin secretion, was } \\
\text { significantly reduced by the half-and } \\
\text { full-dose almonds in comparison to the } \\
\text { control muffin diet after adjustment for } \\
\text { urinary creatinine output. }\end{array}$ & $\begin{array}{l}\text { There were no significant treatment } \\
\text { differences in BW. }\end{array}$ \\
\hline $\begin{array}{l}\text { Claesson, A.L.; et al. } \\
2009 \text { [88] }\end{array}$ & $\begin{array}{l}25(11 / 14) \\
\text { Healthy subjects } \\
\text { (range: } 19-30)\end{array}$ & $\begin{array}{l}\text { Peanuts } \\
\text { Parallel (2 weeks) }\end{array}$ & $\begin{array}{l}\text { Addition of } \\
20 \mathrm{kcal} / \mathrm{kg} \text {-BW of candy } \\
\text { to the regular caloric } \\
\text { intake. }\end{array}$ & $\begin{array}{l}\text { Addition of } \\
20 \mathrm{kcal} / \mathrm{kg}-\mathrm{BW} \text { of roasted } \\
\text { peanuts to the regular } \\
\text { caloric intake. }\end{array}$ & $\begin{array}{l}\text { Plasma-insulin and C-peptide increased } \\
\text { in the candy group, but not in the } \\
\text { peanut group. FBG was not modified. }\end{array}$ & $\begin{array}{l}\text { Energy intake increased similarly in } \\
\text { both groups. BW and WC increased } \\
\text { significantly only in the candy group. } \\
\text { At the end of the study LDL-C and } \\
\text { ApoB/ApoA-1-ratio were higher in the } \\
\text { candy group than in the peanut group. }\end{array}$ \\
\hline $\begin{array}{l}\text { Cohen, A.E.; et al. } \\
\text { (2011) [72] }\end{array}$ & $\begin{array}{l}13(7 / 6) \\
\text { T2D subjects } \\
(66.0 \pm 3.3)\end{array}$ & $\begin{array}{l}\text { Almonds } \\
\text { Parallel (3 months) }\end{array}$ & Nut- free diet & $\begin{array}{l}\text { Diet enriched with } \\
\text { almonds ( } 28 \mathrm{~g}, \\
5 \text { times/week) }\end{array}$ & $\begin{array}{l}\text { Significant reduction of } \mathrm{HbA}_{1 \mathrm{c}} \text { in the } \\
\text { almond group compared to the nut-free } \\
\text { diet group. }\end{array}$ & $\begin{array}{l}\text { Chronic almond ingestion was } \\
\text { associated with a reduction in BMI as } \\
\text { compared with no change in the } \\
\text { nut-free diet group. }\end{array}$ \\
\hline $\begin{array}{l}\text { Li, S.C.; et al. } \\
\text { (2011) [80] }\end{array}$ & $\begin{array}{l}20(9 / 11) \\
\text { T2D subjects } \\
\text { (Mean: } 58)\end{array}$ & $\begin{array}{l}\text { Almonds } \\
\text { Crossover }(1 \mathrm{month} \\
\text { per period) }\end{array}$ & $\begin{array}{l}\text { NCEP step II diet (control } \\
\text { diet); CHO (56 E\%), } \\
\text { protein }(17 \mathrm{E} \%) \text {, and fat } \\
(27 \mathrm{E} \%) \text {. }\end{array}$ & $\begin{array}{l}\text { Almonds were added to } \\
\text { the control diet to replace } \\
20 \% \text { of total daily calorie } \\
\text { intake. }\end{array}$ & $\begin{array}{l}\text { Compared with subjects in the control } \\
\text { diet, those in the almond diet reduced } \\
\text { the levels of fasting insulin, FBG, } \\
\text { and HOMA-IR. }\end{array}$ & $\begin{array}{l}\text { Almond intake decreased TC, LDL-C, } \\
\text { and LDL-C/HDL-C. The almond diet } \\
\text { enhanced plasma } \alpha \text {-tocopherol level } \\
\text { compared with control diet. }\end{array}$ \\
\hline $\begin{array}{l}\text { Damavandi, R.D.; } \\
\text { et al. (2013) [81] }\end{array}$ & $\begin{array}{c}45(15 / 33) \\
\text { Medicated T2D } \\
\text { subjects } \\
(55.68 \pm 7.74)\end{array}$ & $\begin{array}{l}\text { Hazelnuts } \\
\text { Parallel (2 months) }\end{array}$ & Control diet & $\begin{array}{l}10 \% \text { of total daily calorie } \\
\text { intake was replaced with } \\
\text { hazelnuts }\end{array}$ & $\begin{array}{l}\text { No significant differences in FBG } \\
\text { between groups. }\end{array}$ & $\begin{array}{l}\text { No changes in BMI were reported. } \\
\text { Significant HDL-C reduction in control } \\
\text { group was observed. Although the } \\
\text { hazelnut group achieved a greater } \\
\text { reduction in TG concentrations than the } \\
\text { control group, these changes were } \\
\text { non-significant. }\end{array}$ \\
\hline $\begin{array}{l}\text { Hernández-Alonso, P.; } \\
\quad \text { et al. (2014) [85] }\end{array}$ & $\begin{array}{l}54(29 / 25) \\
\text { Subjects with Pre-D } \\
\text { Mean: } 55 \text { (range: } \\
53.4-56.8)\end{array}$ & $\begin{array}{l}\text { Crossover (4 months } \\
\text { per period) }\end{array}$ & $\begin{array}{l}\text { Nut-free diet: the energy } \\
\text { intake of other fatty } \\
\text { foods, mostly olive oil, } \\
\text { was adjusted to } \\
\text { compensate for the } \\
\text { energy from pistachios } \\
\text { included in the PD. }\end{array}$ & $\begin{array}{l}\text { Pistachio diet was } \\
\text { supplemented with } \\
2 \text { ounces of pistachio } \\
(57 \mathrm{~g} / \text { day })\end{array}$ & $\begin{array}{l}\text { FBG, insulin, and HOMA-IR decreased } \\
\text { significantly after the chronic pistachio } \\
\text { period compared with the } \\
\text { nut-free period. }\end{array}$ & $\begin{array}{l}\text { Fibrinogen, oxidized-LDL, and PF-4 } \\
\text { significantly decreased under the } \\
\text { pistachio period compared to the } \\
\text { nut-free period, whereas } \\
\text { GLP-1 increased. }\end{array}$ \\
\hline
\end{tabular}


Table 6. Cont.

\begin{tabular}{|c|c|c|c|c|c|c|}
\hline $\begin{array}{l}\text { First Author (Year) } \\
\text { [Reference] }\end{array}$ & $\begin{array}{c}\mathbf{N}^{\circ} \text { of Subjects }(\mathrm{M} / \mathrm{F} \text { ) } \\
\text { Type of Subjects } \\
\text { (Age in Years) }\end{array}$ & $\begin{array}{l}\text { Nut Study Design } \\
\text { (Length of the } \\
\text { Intervention) }\end{array}$ & Control Group & Intervention Group(s) & $\begin{array}{l}\text { Glucose and Insulin Metabolism } \\
\text { Outcomes }\end{array}$ & Other Outcomes \\
\hline $\begin{array}{l}\text { Lasa, A.; et al. } \\
\text { (2014) [82] }\end{array}$ & $\begin{array}{l}191(77 / 114) \\
\text { T2D subjects } \\
\text { (Mean: 67) }\end{array}$ & $\begin{array}{l}\text { Mixed nuts } \\
\text { Parallel (1 year) }\end{array}$ & LFD & $\begin{array}{l}\text { Mediterranean diets } \\
\text { supplemented with either } \\
\text { virgin olive oil or mixed } \\
\text { nuts }\end{array}$ & $\begin{array}{l}\text { Increased values of the } \\
\text { adiponectin/leptin ratio and } \\
\text { adiponectin/HOMA-IR ratio and } \\
\text { decreased values of WC were observed } \\
\text { in the three groups. }\end{array}$ & $\begin{array}{l}\text { In both Mediterranean diet groups, but } \\
\text { not in the LFD group, this was } \\
\text { associated with a significant reduction } \\
\text { in BW. }\end{array}$ \\
\hline $\begin{array}{l}\text { Parham, M.; et al. } \\
\text { (2014) [83] }\end{array}$ & $\begin{array}{l}44(11 / 33) \\
\text { T2D subjects } \\
\text { (Mean: } 51)\end{array}$ & $\begin{array}{l}\text { Pistachios } \\
\text { Crossover ( } 3 \text { months } \\
\text { per period) }\end{array}$ & $\begin{array}{l}\text { Previous diet without } \\
\text { pistachios }\end{array}$ & $\begin{array}{l}\text { Two snacks of } 25 \mathrm{~g} \\
\text { pistachios/day }\end{array}$ & $\begin{array}{l}\text { Marked decrease in } \mathrm{HbA}_{1 \mathrm{c}} \text { and } \mathrm{FBG} \\
\text { concentrations in the pistachio diet } \\
\text { group compared with the control group. }\end{array}$ & $\begin{array}{l}\text { There were no overall significant } \\
\text { changes in BMI, blood pressure, } \\
\text { HOMA-IR, or CRP concentrations. }\end{array}$ \\
\hline Le, T.; et al. (2016) [87] & $\begin{array}{l}213 \text { women } \\
\text { Ow/Ob subjects } \\
\text { (Mean: 50) }\end{array}$ & $\begin{array}{c}\text { Walnuts } \\
\text { Parallel (1 year) }\end{array}$ & $\begin{array}{c}\text { Control 1: a lower fat } \\
(20 \mathrm{E} \%) \text {, higher } \mathrm{CHO} \\
\text { (65 E\%) diet. } \\
\text { Control 2: lower } \mathrm{CHO} \\
\text { (45 } \mathrm{E} \%) \text {, higher fat } \\
\text { (35 E\%) diet }\end{array}$ & $\begin{array}{l}\text { Walnut-enriched diet: } \\
\text { high fat }(35 \mathrm{E} \%) \text {, lower } \\
\text { CHO }(45 \mathrm{E} \%) \text { diet. }\end{array}$ & $\begin{array}{l}\text { Insulin sensitivity and CRP levels } \\
\text { improved after walnut-rich diet }\end{array}$ & $\begin{array}{l}\text { TG decreased in all study arms at } \\
6 \text { months. The walnut-rich diet } \\
\text { increased HDL-C more than either the } \\
\text { lower fat or lower CHO diet. } \\
\text { The walnut-rich diet also } \\
\text { reduced LDL-C. }\end{array}$ \\
\hline
\end{tabular}

Age is shown as mean \pm SD unless otherwise stated. Apo, apolipoprotein; BMI, Body mass index; BW, body weight; CHO, carbohydrate; CRP, C-reactive protein; E\%, energy percentage; FBG, fasting blood glucose; GLP-1, glucagon-like peptide-1; HA: high almond; $\mathrm{HbA}_{1 \mathrm{c}}$, glycated hemoglobin; HDL-C, high-density lipoprotein cholesterol; HF, high fat; HOMA-IR, homeostatic model assessment of insulin resistance; LDL-C, low-density lipoprotein cholesterol; LF: low fat; LFD, LF diet; M/F, male/female; NCEP, National Cholesterol Education Program; NS, non-significant; Ob, obese; Ow, overweight; PF-4, platelet factor-4; PM, post-menopausal; Pre-D, pre-diabetes; T2D, type 2 diabetes; TC, total cholesterol; TG, triglycerides; WC, waist circumference; WHtR, waist-to-height ratio. 


\subsection{Dried Fruits}

\subsubsection{Acute Clinical Trials on Dried Fruits}

Less research has been carried out into DFs than into nuts. However, the findings to date point to a beneficial effect of DFs on postprandial glucose regulation and glycaemic control in T2D subjects.

The putative effect of DFs on postprandial glycaemia and insulinaemia has been studied mainly using raisins (Table 7). However, some research into dried plums has also been published.

First, in 1989 Rasmussen and coworkers evaluated in healthy and T2D subjects the postprandial effects of three meals: raw rolled oats, oatmeal porridge, or a mixture of raw rolled oats with raisins, compared to a control glucose ingestion [109]. The substitution of $25 \%$ of the starch meal with raisins (i.e., simple sugars) did not affect blood glucose or insulin responses. In addition, a similar glucose and insulin response in both normal and T2D subjects were reported [109]. Other researchers investigated the postprandial effect of raisins consumed alone. When the GI was investigated in three different groups (sedentary, aerobically trained or pre-diabetic subjects), no significant differences were found among groups, even though the GI (55-69) it seemed moderate for aerobically trained adults, and low (GI, $\leq 55)$ for the other groups [110]. Kanellos and collaborators found a moderate GI of raisins in healthy and T2D subjects [111], whereas Esfahani et al. found that raisins were low-GI and glycaemic load (GL) foods in healthy subjects [112]. Recently, researchers have found that even though the same available $\mathrm{CHO}$ content from raisins and glucose generated a similar postprandial response, raisins significantly modulated the levels of GIP, ghrelin and ghrelin/obestatin ratio, with important implications in terms of appetite regulation and overall insulin secretion [113]. In overweight women, researchers determined that dried plums had a lower plasma glucose and insulin incremental area under the curve (IAUC) than an isoenergetic low-fat cookie meal [114].

Overall, results suggest that raisins have a beneficial postprandial glucose and insulin effect, which may cautiously be extrapolated to other DFs considering their overall macronutrient composition. 
Table 7. Summary of acute clinical studies analyzing the effect of dried fruit consumption on postprandial response.

\begin{tabular}{|c|c|c|c|c|c|c|}
\hline $\begin{array}{l}\text { First Author (Year) } \\
\text { [Reference] }\end{array}$ & $\begin{array}{c}\mathrm{N}^{\circ} \text { of Subjects }(\mathrm{M} / \mathrm{F}) \\
\text { Type of Subject } \\
\text { (Age in Years) }\end{array}$ & $\begin{array}{c}\text { Dried Fruit } \\
\text { (Study Design) }\end{array}$ & Control Group & Intervention Group(s) & $\begin{array}{l}\text { Glucose and Insulin Metabolism } \\
\text { Outcomes }\end{array}$ & Other Outcomes \\
\hline $\begin{array}{l}\text { Rasmussen, O.; et al. } \\
\text { (1989) [109] }\end{array}$ & $\begin{array}{c}20(9 / 11) \\
\text { Healthy }(n=11) \text { and } \\
\text { T2D subjects }(n=9) \\
\text { (Healthy: } 30 \pm 2 ; \mathrm{T} 2 \mathrm{D} \\
\text { subjects: } 67 \pm 2)\end{array}$ & Raisins (crossover) & $\begin{array}{l}75 \mathrm{~g} \text { (healthy) or } 50 \mathrm{~g} \\
\text { (T2D) of CHO }\end{array}$ & $\begin{array}{l}\text { Raw rolled oats; oatmeal } \\
\text { porridge or a mixture of } \\
\text { raw rolled oats with } \\
\text { raisins }\end{array}$ & $\begin{array}{l}\text { Substitution of } 25 \% \text { of the starch meal } \\
\text { with raisins (simple sugars) did not affect } \\
\text { blood glucose or insulin responses }\end{array}$ & $\begin{array}{l}\text { In normal and T2D subjects, the three } \\
\text { meals produce similar glucose and } \\
\text { insulin response curves. }\end{array}$ \\
\hline $\begin{array}{l}\text { Kim, Y.; et al. (2008) } \\
\text { [110] }\end{array}$ & $\begin{array}{l}10 \mathrm{~S} ; 11 \mathrm{AT} \text { and } \\
10 \text { Pre-D } \\
(\mathrm{S}(25.7 \pm 1.3), \mathrm{AT} \\
(23.1 \pm 1.0), \text { Pre-D } \\
(50.0 \pm 2.6))\end{array}$ & $\begin{array}{l}\text { Raisins } \\
\text { (crossover) }\end{array}$ & $\begin{array}{l}50 \mathrm{~g} \text { of available } \mathrm{CHO} \\
\text { from glucose }\end{array}$ & $\begin{array}{l}50 \mathrm{~g} \text { of available } \mathrm{CHO} \\
\text { from raisins }\end{array}$ & $\begin{array}{l}\text { NS differences among groups. The GI of } \\
\text { raisins seemed lower }(\leq 55) \text { in the } S \text { and } P \\
\text { groups compared to moderate }(G I, 56-69) \\
\text { in the A group. The insulinaemic index of } \\
\text { raisins was not different among groups. }\end{array}$ & \\
\hline $\begin{array}{l}\text { Furchner-Evanson, A.; } \\
\text { et al. (2010) [114] }\end{array}$ & $\begin{array}{l}19 \text { women } \\
\text { ow subjects } \\
(39.2 \pm 0.7)\end{array}$ & $\begin{array}{l}\text { Dried plums } \\
\text { (crossover) }\end{array}$ & $\begin{array}{l}\text { White bread } \\
(238 \mathrm{Kcal})\end{array}$ & $\begin{array}{l}\text { Dried plums }(238 \mathrm{Kcal}) \\
\text { Low-fat cookies } \\
(238 \text { Kcal })\end{array}$ & $\begin{array}{l}\text { Dried plums elicited lower plasma glucose } \\
\text { and insulin IAUC than low-fat cookies. }\end{array}$ & $\begin{array}{l}\text { The satiety index IAUC was greater for } \\
\text { the dried plums than low-fat cookies, } \\
\text { and tended to promote a greater plasma } \\
\text { ghrelin AOC }\end{array}$ \\
\hline $\begin{array}{l}\text { Kanellos, P.T.; et al. } \\
\text { (2013) [111] }\end{array}$ & $\begin{array}{c}30(17 / 13) \\
\text { Healthy and T2D } \\
\text { subjects }(n=15 \text { each) } \\
\text { (Healthy: } 25.9 \pm 0.8 \\
\text { T2D: } 63.2 \pm 1.7)\end{array}$ & $\begin{array}{l}\text { Corinthian raisins } \\
\text { (crossover) }\end{array}$ & $50 \mathrm{~g}$ of glucose & $\begin{array}{l}74 \mathrm{~g} \text { of Corinthian raisins; } \\
50 \mathrm{~g} \text { of available } \mathrm{CHO}\end{array}$ & $\begin{array}{l}\text { Significantly different glucose peaks } \\
\text { between raisins and glucose in healthy } \\
\text { and in diabetic subjects. Glycaemic and } \\
\text { insulinaemic responses were decreased } \\
\text { after raisin consumption compared to } \\
\text { glucose ingestion. }\end{array}$ & \\
\hline $\begin{array}{l}\text { Esfahani, A.; et al. } \\
\text { (2014) [112] }\end{array}$ & $\begin{array}{l}10(4 / 6) \\
\text { Healthy subjects } \\
\quad(39 \pm 11)\end{array}$ & $\begin{array}{l}\text { Raisins } \\
\text { (crossover) }\end{array}$ & $\begin{array}{l}108 \mathrm{~g} \text { of white bread; } \\
50 \mathrm{~g} \text { available CHO } \\
\text { (consumed on two } \\
\text { separate occasions) }\end{array}$ & $\begin{array}{l}\text { R50: } 69 \mathrm{~g} \text { raisins; } 50 \mathrm{~g} \\
\text { available CHO } \\
\text { R20: } 28 \text { g raisins; } 20 \mathrm{~g} \\
\text { available } \mathrm{CHO}\end{array}$ & $\begin{array}{l}\text { The raisin meals, R50 and R20, resulted in } \\
\text { significantly reduced postprandial glucose } \\
\text { and insulin responses compared with } \\
\text { white bread }\end{array}$ & $\begin{array}{l}\text { Raisins were determined to be low in GI, } \\
\text { GL and insulinaemic index. }\end{array}$ \\
\hline $\begin{array}{l}\text { Kaliora, A.C.; et al. } \\
\quad \text { (2017) [113] }\end{array}$ & $\begin{array}{l}10 \\
\text { Healthy } \\
\text { normo-weight } \\
\text { subjects } \\
(26.3 \pm 0.8)\end{array}$ & $\begin{array}{l}\text { Raisins } \\
\text { (crossover) }\end{array}$ & $50 \mathrm{~g}$ of glucose & $\begin{array}{l}74 \mathrm{~g} \text { of raisins; } 50 \mathrm{~g} \text { of } \\
\text { available } \mathrm{CHO}\end{array}$ & $\begin{array}{l}\text { At } 60 \mathrm{~min} \text {, glucose and insulin levels were } \\
\text { maximum in both groups. }\end{array}$ & $\begin{array}{l}\text { GIP was lower after raising intake } \\
\text { compared to glucose intake at } 60 \text { and } \\
120 \text { min postprandially. Ghrelin was } \\
\text { lower after raisin compared to glucose } \\
\text { intake at } 120 \text { and at } 180 \text { min } \\
\text { post-ingestion. No differences were } \\
\text { reported for GLP-1, apelin or obestatin } \\
\text { in either trial. }\end{array}$ \\
\hline
\end{tabular}

Age is shown as mean + SD unless otherwise stated. AT, aerobically trained; AOC, area over the curve; $\mathrm{CHO}$, carbohydrates; GI, glycaemic index; GL, glycaemic load; GLP-1, glucagon-like

peptide-1; IAUC, incremental area under the curve; M/F, male/female; NS, non-significant; ow, overweight; Pre-D, pre-diabetic; S, sedentary; T2D, type 2 diabetes; WB, white bread. 


\subsubsection{Chronic Clinical Trials on Dried Fruits}

The study of the beneficial effects of chronic DF consumption also focuses on raisins (Table 8). Randomized clinical trials have been conducted in healthy [115], overweight or obese [116,117], T2D subjects [118,119], or a combination of the three [120]. In a 6-week parallel trial in healthy subjects, Puglisi et al. included $150 \mathrm{~g} /$ day of raisins into subjects' habitual diet or increased their physical activity (or combined them both). Neither FPG nor insulin levels were different among groups or compared to baseline. However, the inflammation status reported by plasma TNF- $\alpha$ significantly decreased in the raisin intervention [115].

The results for overweight or obese subjects do not show a significant improvement in glucose or insulin levels after the consumption of raisins [116] or dried plums [117]. However, these studies are only short ( 2 weeks) which makes it impossible to analyze the chronic effect. In fact, in a parallel study conducted in $\mathrm{Ow} / \mathrm{Ob}$ subjects, comparing raisin consumption $(270 \mathrm{Kcal} /$ day $)$ with a snack (300 Kcal/day) for 12 weeks, researchers [120] found that even though FGP or insulin were not affected by either intervention, $\mathrm{HbA}_{1 \mathrm{c}}$ levels and postprandial glucose levels had been reduced by raisin consumption by the end of the trial. This suggests a beneficial effect of raisin consumption on glycaemic control in Ow/Ob subjects with pre-D. Importantly, raisin intake also improved systolic blood pressure (SBP) and diastolic blood pressure (DBP) and had a null effect on body weight [120].

Two studies have been conducted in individuals with T2D. A parallel study comparing the consumption of $36 \mathrm{~g}$ of raisins versus the habitual diet free of raisins or grapes for 24 weeks did not find any change in either body weight or in glycaemic control and lipid profile, but the total antioxidant capacity increased and the DBP decreased after raisin consumption [118]. Likewise, the consumption of raisins as a snack ( $84 \mathrm{~g} /$ day, $270 \mathrm{Kcal} /$ day) for 12 weeks significantly reduced the postprandial glucose response in T2D subjects compared to an alternative snack ( $300 \mathrm{Kcal} /$ day) for 12 weeks. A non-significant trend to a reduction in fasting glucose and $\mathrm{HbA}_{1 \mathrm{c}}$ was also observed in the same group of raisin consumers [119].

The results of DF consumption on glycaemia/insulinaemia point to a beneficial effect. However, novel acute and long-term RCTs assessing other types of DF should be carried out in order to corroborate and expand what is known about raisins. 
Table 8. Summary of chronic clinical trials and their characteristics in the context of dried fruit consumption.

\begin{tabular}{|c|c|c|c|c|c|c|}
\hline $\begin{array}{l}\text { First Author (Year) } \\
\text { [Reference] }\end{array}$ & $\begin{array}{c}\mathrm{N}^{\circ} \text { of Subjects }(\mathrm{M} / \mathrm{F}) \\
\text { Type of Subject } \\
\text { (Age in Years) }\end{array}$ & $\begin{array}{l}\text { Study Design } \\
\text { (Length of the } \\
\text { Intervention) }\end{array}$ & Control Group & $\begin{array}{l}\text { Intervention } \\
\text { Group(s) }\end{array}$ & $\begin{array}{l}\text { Glucose and Insulin } \\
\text { Metabolism Outcomes }\end{array}$ & Other Outcomes \\
\hline $\begin{array}{l}\text { Puglisi, M.J.; et al. } \\
\text { (2008) [115] }\end{array}$ & $\begin{array}{l}34(17 / 17 \text { PM) } \\
\text { Healthy } \\
\text { (range: } 50-70)\end{array}$ & $\begin{array}{l}\text { Raisin } \\
\text { Parallel (6 weeks) }\end{array}$ & $\begin{array}{l}\text { Walk (increase in the } \\
\text { steps taken per day) }\end{array}$ & $\begin{array}{l}150 \mathrm{~g} / \text { day of raisins. } \\
\text { Walk }+150 \mathrm{~g} / \text { day } \\
\text { of raisins }\end{array}$ & $\begin{array}{l}\text { Changes in FBG and insulin values did } \\
\text { not differ among intervention groups or } \\
\text { from baseline. Plasma TNF- } \alpha \text { decreased in } \\
\text { the raisin group but no differences were } \\
\text { reported between groups. }\end{array}$ & $\begin{array}{l}\text { Plasma TC and LDL-C decreased in all the } \\
\text { intervention groups. }\end{array}$ \\
\hline $\begin{array}{l}\text { Rankin, J.W.; et al. } \\
\text { (2008) [116] }\end{array}$ & $\begin{array}{c}17(8 / 9) \\
\text { Ow } \\
(26.5 \pm 7.6)\end{array}$ & $\begin{array}{c}\text { Raisin } \\
\text { Crossover } \\
\text { (2 weeks per period) }\end{array}$ & $\begin{array}{l}\text { Jelly candy } \\
\text { (264 Kcal/day) }\end{array}$ & $\begin{array}{l}90 \mathrm{~g} / \text { day raisins } \\
\text { (264 Kcal/day) }\end{array}$ & $\begin{array}{l}\text { NS changes in FBG or markers of } \\
\text { inflammation or endothelial dysfunction } \\
\text { after the raisin intervention. }\end{array}$ & $\begin{array}{l}\text { Fasting protein-free ORAC was modestly } \\
\text { higher after the raisin intervention than } \\
\text { the jelly candy intervention. }\end{array}$ \\
\hline $\begin{array}{l}\text { Howarth, L.; et al. } \\
\text { (2010) [117] }\end{array}$ & $\begin{array}{l}26 \text { women } \\
\text { Ow/Ob } \\
\text { (range: } 25-54)\end{array}$ & $\begin{array}{l}\text { Dried plums } \\
\text { Crossover (2 weeks } \\
\text { per period) }\end{array}$ & $\begin{array}{l}\text { Low-fat cookies } \\
\text { (200 Kcal/day) }\end{array}$ & $\begin{array}{l}\text { Dried plums } \\
\text { (200 Kcal/day) }\end{array}$ & $\begin{array}{l}\text { No changes were found in plasma glucose } \\
\text { or insulin levels in any intervention. }\end{array}$ & $\begin{array}{l}\text { Plasma TG concentration was unchanged } \\
\text { by dried plum consumption and was } \\
\text { higher after the consumption of low-fat } \\
\text { cookies. Incorporation of dried plums or } \\
\text { low-fat cookies into the diet did not alter } \\
\text { energy intake or BW. }\end{array}$ \\
\hline $\begin{array}{l}\text { Anderson, J.W.; et al. } \\
\text { (2014) [120] }\end{array}$ & $\begin{array}{c}46(21 / 25) \\
\text { Ow/Ob with Pre-D or } \\
\text { at T2D risk. } \\
\text { (snack (mean: } 61.1), \\
\text { raisins (mean: } 60.3) \text { ) }\end{array}$ & $\begin{array}{l}\text { Raisins } \\
\text { Parallel } \\
\text { (12 weeks) }\end{array}$ & $\begin{array}{c}\text { Snacks } \\
\text { (300 Kcal/day) }\end{array}$ & $\begin{array}{l}84 \text { g/day of raisins } \\
\text { (270 Kcal/day) }\end{array}$ & $\begin{array}{l}\text { Fasting } \mathrm{HbA}_{1 \mathrm{c}} \text { levels were significantly } \\
\text { reduced after raisin intake, whereas FBG } \\
\text { and insulin levels were not significantly } \\
\text { affected by the intake of raisins or snacks. } \\
\text { Postprandial glucose levels were } \\
\text { significantly reduced by raisin intake vs. } \\
\text { snacks. }\end{array}$ & $\begin{array}{l}\text { Raisin intake was associated with } \\
\text { reductions in SBP and DBP. BW did not } \\
\text { significantly change within or } \\
\text { between groups. }\end{array}$ \\
\hline $\begin{array}{l}\text { Kanellos, P.T.; et al. } \\
\text { (2014) [118] }\end{array}$ & $\begin{array}{c}48(25 / 23) \\
\mathrm{T} 2 \mathrm{D} \\
\text { (raisins }(63.7 \pm 6.3) \\
\text { control }(63 \pm 8.5))\end{array}$ & $\begin{array}{l}\text { Corinthian raisins } \\
\text { Parallel } \\
\text { (24 weeks) }\end{array}$ & $\begin{array}{l}\text { Usual diet avoiding } \\
\text { grapes and raisins }\end{array}$ & $\begin{array}{l}36 \mathrm{~g} / \text { day of } \\
\text { Corinthian raisins }\end{array}$ & $\begin{array}{l}\text { BW, glycaemic control, and lipid profile } \\
\text { were not changed in either arm of the } \\
\text { intervention. Patients in the CR arm } \\
\text { reduced their DBP and increased their } \\
\text { total antioxidant potential compared with } \\
\text { baseline values and the control group. }\end{array}$ & $\begin{array}{l}\text { No change in CRP was observed. } \\
\text { A significant difference in plasma } \\
\text { circulating p-hydroxybenzoic acid was } \\
\text { observed between groups at the end of } \\
\text { the trial. }\end{array}$ \\
\hline $\begin{array}{l}\text { Bays, H.; et al. } \\
\text { (2015) [119] }\end{array}$ & $\begin{array}{l}46(19 / 27) \\
\text { T2D } \\
\text { (mean: 58) }\end{array}$ & $\begin{array}{c}\text { Dark raisins } \\
\text { Parallel (12 weeks) }\end{array}$ & $\begin{array}{l}\text { Snack group } \\
\text { (300 Kcal/day) }\end{array}$ & $\begin{array}{l}84 \mathrm{~g} / \text { day of dark } \\
\text { raisins group } \\
\text { (270 Kcal/day) }\end{array}$ & $\begin{array}{l}\text { Compared to the snack group, those who } \\
\text { consumed raisins reduced their } \\
\text { postprandial glucose levels, and an NS } \\
\text { trend to a reduction in fasting glucose and } \\
\mathrm{HbA}_{1 \mathrm{c}} \text {. NS changes in BW, fasting insulin, } \\
\text { HOMA-IR or lipid profile between } \\
\text { intervention groups. }\end{array}$ & $\begin{array}{l}\text { Compared to alternative processed snacks, } \\
\text { those who consumed raisins had a } \\
\text { significant reduction in SBP but not a } \\
\text { significant reduction in DBP. }\end{array}$ \\
\hline
\end{tabular}

Age is shown as mean \pm SD unless otherwise stated. BW, body weight; $C R P$, C-reactive protein; DBP, diastolic blood pressure; FBG, fasting blood glucose; HbA ${ }_{1 c}$, glycated hemoglobin; HOMA-IR, homeostatic model assessment of insulin resistance; LDL-C, low-density lipoprotein cholesterol; M/F, male/female; NS, non-significant; Ob, obese; ORAC, oxygen radical absorbance capacity; Ow, overweight; pre-D, pre-diabetes; PM, postmenopausal women; SBP, systolic blood pressure; T2D, type 2 diabetes; TC, total cholesterol; TG, triglycerides; TNF- $\alpha$, tumor necrosis factor- $\alpha$ 


\section{Potential Mechanisms Linking Nut and Dried Fruit Consumption to Glucose and Insulin Metabolism}

\subsection{Nut- and Dried Fruit-Related Nutrients and Their Role in Glucose and Insulin Metabolism}

Fiber Content in Nuts and Dried Fruits

Both nuts and DFs are high in dietary fiber [9]. Diets rich in complex $\mathrm{CHO}$ and fiber are associated with increased insulin sensitivity and reduced plasma insulin levels, promoting better glycaemic control in diabetic patients [121]. Soluble fiber increases gastric distension, viscosity in the gastrointestinal tract, and slower absorption of macronutrients [122]. As a consequence, the speed of $\mathrm{CHO}$ absorption and the concentration of postprandial glucose tend to be lower after the ingestion of fiber-rich foods than foods or meals poor in fibers [123].

Fiber is resistant to enzymatic digestion in the small intestine and thus susceptible to fermentation by bacteria in the colon. It produces short chain fatty acids (SCFA, e.g., acetate, propionate and butyrate) which reduce the production of hepatic glucose and stimulate the secretion of GLP-1 [124,125]. Incretins such as GLP-1 and gastric inhibitory polypeptide (GIP) stimulate the secretion of insulin by $\beta$-cells and promote the proliferation of these cells, favoring the maintenance of normal blood glucose levels [125]. The secretion of GLP-1-which is mainly performed by enteroendocrine L-cells of the gastrointestinal tract -is partly mediated by monosaccharides, peptides and amino-acids, MUFA and PUFA as well as by SCFA. Therefore, the positive influence of GLP-1 on blood glucose homeostasis, appetite sensations, and food intake provides a strong rationale for its therapeutic potential in the nutritional management of T2D and obesity [126].

Overall fiber contained in nuts and DFs is also able to decrease postprandial glycaemic levels and this could be a strategy for increasing insulin sensitivity which improves T2D and several other CV risk factors for chronic diseases [74,127].

Carbohydrate Content-Glycaemic Index of Nuts and Dried Fruits

It should be noted that nuts are relatively low in $\mathrm{CHO}$ (approximately $15 \%$ of the total energy) whereas DFs have a high amount of $\mathrm{CHO}(60-80 \%)$. Nuts have a low glycaemic index and therefore increase the blood glucose level less and require less insulin secretion, thus favoring the control of T2D. However, because DFs are high in carbohydrates and fiber, their specific GI has been the object of considerable study. The GI of raisins was first evaluated in three heterogeneous groups of subjects (aerobically trained, sedentary or pre-diabetic) and was described between 49 and 69, therefore corresponding to the low-to-moderate GI foods [110]. However, later studies have reported that raisins are in the low GI category in healthy subjects (a GI of 49.4 and an insulinemic index of 47.1) [15]. This suggests a favorable postprandial glucose and insulin response [112], that could be explained by the high proportion of fructose that DFs contain.

Overall, the inclusion of both nuts and DFs in a balanced diet may reduce the overall glycaemic index of the diet, with benefits to glycaemic and insulinemic control in both healthy and T2D subjects [128].

\section{Fat Content in Nuts}

The high content of MUFA and PUFA in nuts seems to enhance the reduction of IR, thus consequently reducing the risk of developing T2D [129-131]. However, the mechanisms by which these fatty acids (FA) affect insulin sensitivity are not yet fully understood [132]. It is believed, however, that the FAs present in the phospholipids of different cell membranes are affected by the type of fatty acid intake, thus affecting insulin sensitivity. The different unsaturated FAs that are part of the cell membrane influence the action of insulin via affecting the binding or affinity of insulin to its cellular receptor [133]. It is hypothesized that a higher unsaturation of FA in the cell membrane facilitates the movement of the glucose receptor to the cell surface, thus increasing insulin sensitivity [134]. 
In addition, as we have seen, unsaturated fatty acids act through the stimulation of GLP-1 secretion, thus improving the efficiency of $\beta$-cells. SFA and MUFA act on the lipogenic gene expression, while PUFA inhibit the expression of these genes, partly by binding and activating nuclear receptors, such as those activated by peroxisome proliferators (PPAR) [131]. It has been suggested that the activation of PPAR has a therapeutic role in the treatment of T2D, because it induces fatty acid clearance by the adipose tissue, decreasing its plasma levels and thus increasing insulin sensitivity in the muscle [135].

\section{Mineral Content in Nuts and Dried Fruits}

Nuts contain relatively high quantities of different minerals such as potassium, magnesium and calcium, whereas DF contains more moderate quantities (mainly potassium, magnesium and boron). Magnesium has been associated with beneficial effects on glycaemic control [136]. Low magnesium levels have been implicated in IR development [124]. In fact, kidneys lose the ability to retain magnesium in periods of acute hyperglycemia. It is excreted in the urine, leading to low mineral blood levels. It has been shown that correcting this depletion improves response and insulin action. Magnesium deficiency also interferes with the reactions that use or produce ATP, thus altering the enzyme cascade involved in the CHO metabolism and favoring the development of T2D [137].

Therefore, the minerals present in nuts and DF could explain the relationship observed between magnesium intake and the lower risk of developing T2D and other chronic diseases [138,139].

\section{Other Bioactive Compounds in Nuts and Dried Fruits}

The other bioactive compounds contained in nuts and DF could partially explain their protective anti-oxidant and anti-inflammatory properties [2] and their implication in glucose and insulin metabolism (and therefore in T2D). Significant evidence suggests that polyphenol-rich diets have the ability to protect against diabetes [140]. It appears that anthocyanins (or anthocyanin-rich foods) are inversely associated to the risk of T2D, but there is no association for other polyphenol subclasses $[141,142]$. Dietary polyphenols have some benefits for T2D: they protect pancreatic $\beta$-cells against glucose toxicity and they have anti-inflammatory and anti-oxidant effects, among other things. Quercetin is a member of the flavonoid class of polyphenols which is abundant in such foods as fruits, vegetables, nuts and seeds [143]. Several in vitro studies have sought to elucidate the mechanisms behind the antidiabetic properties of quercetin: for example the inhibition of the $\alpha$-amylase and $\alpha$-glucosidase activities, and the prevention of the lipid peroxidation of pancreatic tissue homogenates [144]. Moreover, ellagic acid (EA) is another polyphenol which naturally occurs in some fruits, such as berries (strawberries and red and black raspberries), nuts, and pomegranates [145]. There is emerging in vitro evidence that EA may ameliorate symptoms of chronic metabolic diseases-by decreasing chronic inflammation at the expression level—which include dyslipidemia, IR and T2D [146-148]. Despite the growing amount of information on EA, a definitive mechanism of action has not been established. This may be attributed to the complexity of EA metabolism, which is governed by various factors [145].

A growing body of evidence suggests that dietary agents and the non-nutrient components of fruits, vegetables and nuts can affect epigenetic processes related to T2D [149,150]. Epigenetics generally refers to heritable and reversible changes affecting gene expression and chromatin organization that are not due to alterations in the DNA sequence [151,152]. No specific data is available on the role of nuts and DFs in T2D epigenetics. However, dietary polyphenol resveratrol-most abundant in the skin of grapes and raisins, but also found in peanuts and cranberries [153]—and other phytochemicals (e.g., curcumin) have proved to be effective agents against cancer and to act through epigenetic mechanisms that affect the global epigenome [154,155]. However, future studies are needed to determine the biological importance of the altered tissue-specific DNA methylation in T2D resulting from nutritional modifications [152]. 
5.2. Cellular and Molecular Mechanisms Linking Nut and Dried Fruit Consumption and the Prevention and/or Management of T2D/IR

Gene Expression

Some studies have analyzed the effect of nut and DF consumption on changes in the gene expression of particular cells and/or tissues and its relationship with glucose and insulin metabolism or T2D. In particular, a crossover study conducted in pre-diabetic subjects consuming pistachio for 4 months reported a downregulation of interleukin-6 (IL-6) and resistin (RETN) genes in leukocytes, whereas the pistachio diet led to a lower significant increase of solute carrier family 2 member 4 (SLC2A4, codifying GLUT4) [85]. Consistent with this attenuation in the expression of glucose transporters, leukocytes significantly reduced the uptake of glucose following pistachio consumption, suggesting a decrease in the cell hyperactivity described in T2D.

To our knowledge no published studies have evaluated gene expression after the consumption of DF. However, a translational study conducted in 120 healthy young subjects has shown that individuals in the highest tertile of fruit and vegetable consumption had statistically lower values of the expression of some pro-inflammatory marker genes such as intercellular adhesion molecule-1 (ICAM-1), IL-6 and TNF- $\alpha$, in peripheral blood mononuclear cells (PBMC) [156].

Therefore, these results shed new light on the nutrient-gene interactions in nuts and DFs. However, further research is needed.

\section{MicroRNAs}

The modulatory role of nuts and DF on the expression of genes related to inflammation, oxidative stress and glucose metabolism can also be mediated by the effect of nutrients on microRNAs. MicroRNAs (miRNAs) are RNA molecules that belong to a family of small non-coding RNAs with 20 to 25 nucleotides $[157,158]$ that post-transcriptionally and negatively regulate gene expression.

Research into the nutritional modulation of miRNA is still in its infancy and few studies have assessed whether a specific dietary pattern, food, supplements or a particular nutrient can influence miRNA levels [159]. In humans, consumption of grape extract rich in resveratrol, and Vitamin supplementation modulated specific miRNAs towards a healthier status [160]. Similarly, a PUFA-enriched diet including almonds and walnuts was effective at modifying several miRNAs [161]. More recently, pistachio consumption in pre-diabetic subjects significantly diminished the levels of miR-375 and miR-192, both related to the glucose and insulin metabolism [162]. However, there is still much to discover about the exact mechanisms linking miRNAs with the glucose and insulin metabolism and the dietary modulation of miRNA expression.

Microbiota and Metabolomic Modulation

In recent years, many studies have pointed out that the gut microbiome might make an important contribution to the development of insulin resistance and T2D. Several mechanisms related to the composition of gut microbes-including changes in bowel permeability, endotoxemia and interaction with bile acids-may contribute to the onset of insulin resistance. On the other hand, it is well established that long-term dietary patterns and shorter-term dietary variation influence gut microbiota composition [163]. Many potential prebiotic components can be present in a particular food. For example, the fermentation of fiber from nuts and DF to beneficial end-products (e.g., butyric acid) and the biotransformation of phytochemicals (i.e., tocopherols, phytosterols, and phenolic compounds) are associated with the transition to a healthier microbiota composition [2,164].

There is little information on the putative effect of nuts and DF on microbiota modulation. In fact, only two publications have evaluated the effect of nut consumption (almonds and pistachios) on changes in microbiota. Mandalari et al. conducted an in vitro study with almond skins and they found that almond fiber significantly altered the composition of gut bacteria, specifically Bifidobacteria, thus showing that almond skins had a potential prebiotic use [165]. Some years later, Ukhanova and 
collaborators carried out two separate crossover feeding trials with nuts and pistachios, and showed that they both significantly affected microbiota modulation [166]. However, a greater prebiotic effect was found after pistachio intake. In fact, pistachio increased the number of butyrate-producing bacteria, which are potentially beneficial, whereas the numbers of Bifidobacteria were not affected by the consumption of either nut [166].

Recently, dietary polyphenols have been found to be involved in gut microbiota dysbiosis processes which may lead to a reduction of fat storage, inflammation and IR (reviewed in [167]). In fact, a cranberry extract also altered the gut microbiome of mice by increasing mucin-degrading bacteria, a potential link to reverse the dysbiosis and metabolic inflammation underlying T2D [168].

Very few studies have been made on metabolomic modulation after nut and DF intake. Of the studies that have been made, some have evaluated changes in metabolites after a chronic consumption of nuts. They showed a modulation in the levels of metabolites such as raffinose, (12Z)-9,10-dihydroxyoctadec-12-enoate, sucrose, together with some modulations of plasma amino acids and fatty acids [169], and a modulation of gut-related metabolites and cis-aconitate, an intermediate of tricarboxylic acid [170], after pistachio consumption.

Therefore, several specific nutrients-together with their synergic effects-in both nuts and DFs may explain their beneficial role in glucose and insulin metabolism, which helps to prevent or maintain T2D (Figure 1).

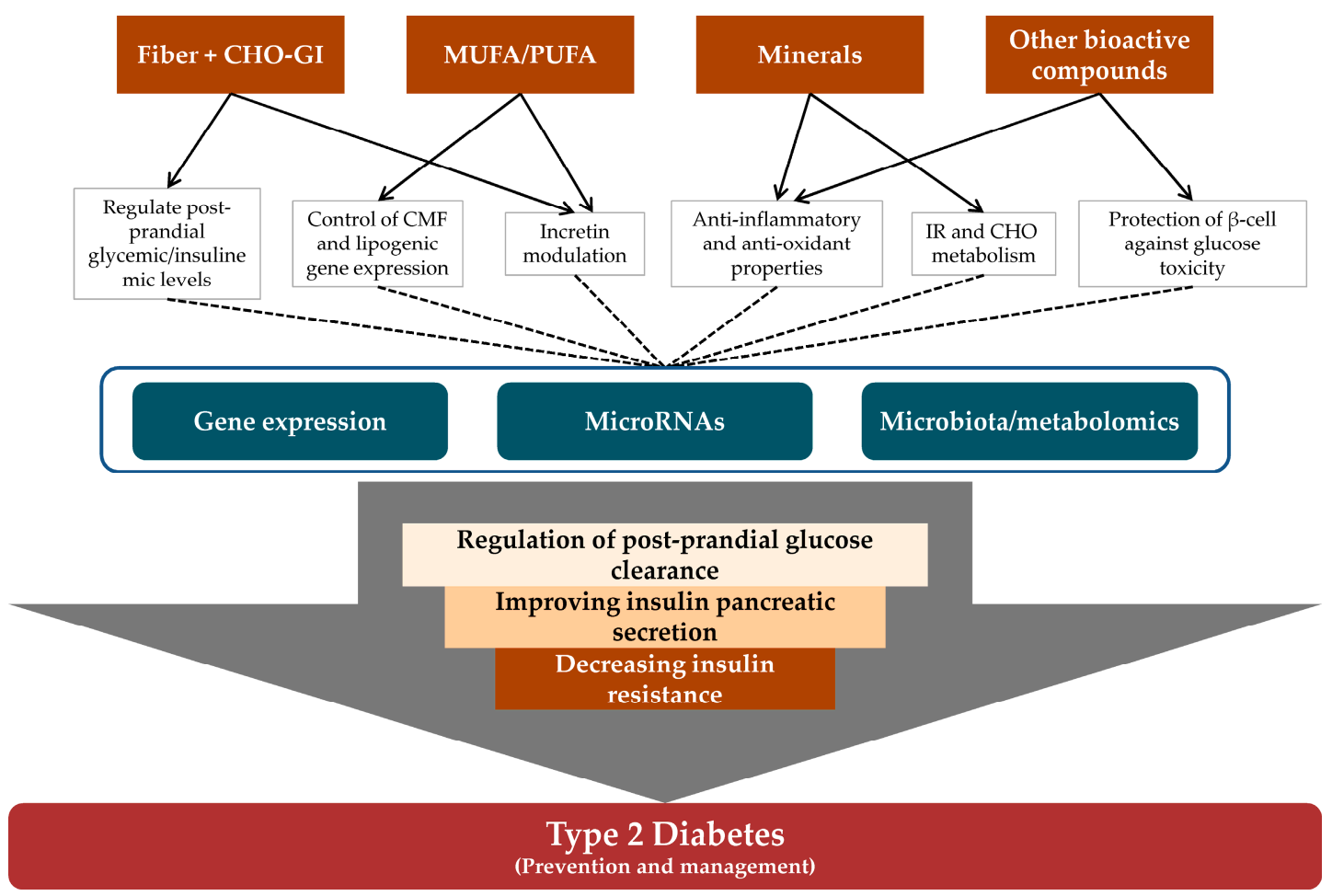

Figure 1. Role of nutrients from nuts and dried fruits in glucose and insulin metabolism, and cellular and molecular mechanisms related to T2D/IR. CHO, carbohydrate; CMF, cellular membrane fluidity; GI, glycaemic index; IR, insulin resistance; MUFA, monounsaturated fatty acid; PUFA, polyunsaturated fatty acid; T2D, type 2 diabetes.

\section{Concluding Remarks}

Undoubtedly, the specific composition of nuts and dried fruits means that they can be used to efficiently counteract metabolic diseases such as type 2 diabetes. Their unique profile of macronutrients, micronutrients and other bioactive compounds may explain the beneficial effects observed in clinical and epidemiological studies. However, the exact mechanisms by which they modulate glucose and 
insulin metabolism and influence T2D have yet to be fully discovered. They contain fiber, fat, minerals and other bioactive molecules that modulate several gene mechanisms at the cellular and molecular level. This may explain some of their beneficial effects. However, further basic and translational research is needed in order to extend their positive health benefits and to find novel mechanisms and targets to explain their contribution to the management of type 2 diabetes.

Acknowledgments: We thank Carles Munné and Susana Segura (Universitat Rovira i Virgili) for their help as editor assistance. Lucía Camacho-Barcia is the recipient of a pre-doctoral fellowship from the Generalitat de Catalunya's Department of Universities (FI-DGR 2017).

Author Contributions: Pablo Hernández-Alonso, Lucía Camacho-Barcia, Mònica Bulló and Jordi Salas-Salvadó designed the review. Pablo Hernández-Alonso, Lucía Camacho-Barcia and Mònica Bulló performed the bibliographical search. Pablo Hernández-Alonso, Lucía Camacho-Barcia, Mònica Bulló and Jordi Salas-Salvadó wrote the first draft of the manuscript, and all authors contributed to the editing of the manuscript. All authors approved the final manuscript.

Conflicts of Interest: Pablo Hernández-Alonso, Lucía Camacho-Barcia and Mònica Bulló have nothing to declare. Jordi Salas-Salvadó is a nonpaid member of the Scientific Advisory Council of the International Nut Council.

\section{Abbreviations}

$\begin{array}{ll}\text { AMPK } & \text { adenosine monophosphate-activated protein kinase } \\ \text { AT } & \text { aerobically trained } \\ \text { ATP } & \text { adenosine triphosphate } \\ \text { AOC } & \text { area over the curve } \\ \text { Apo } & \text { apolipoprotein } \\ \text { BMI } & \text { body mass index } \\ \text { BW } & \text { body weight } \\ \text { C } & \text { cholesterol } \\ \text { CHO } & \text { carbohydrate } \\ \text { CI } & \text { confidence interval } \\ \text { CMF } & \text { cellular membrane fluidity } \\ \text { CRP } & \text { C-reactive protein } \\ \text { CVD } & \text { cardiovascular disease } \\ \text { DF } & \text { dried fruit } \\ \text { EA } & \text { ellagic acid } \\ \text { EPIC } & \text { European Prospective Investigation into Cancer } \\ \text { FA } & \text { fatty acid } \\ \text { FBG } & \text { fasting blood glucose } \\ \text { FBP } & \text { fructose-1,6-bisphosphatase } \\ \text { G6Pase } & \text { glucose 6-phosphatase } \\ \text { GAE } & \text { gallic acid equivalents } \\ \text { GI } & \text { glycaemic index } \\ \text { GIP } & \text { gastric inhibitory polypeptide } \\ \text { GL } & \text { glycaemic load } \\ \text { GJ } & \text { grape juice } \\ \text { GLI } & \text { incremental area under the curve } \\ \text { GLP-1 } & \text { glibenclamide } \\ \text { GLUT } & \text { glucagon-like peptide-1 } \\ \text { GPE } & \text { glucose transporter type } \\ \text { HA } & \text { grape powder extract } \\ \text { HbA } 1 \text { high almond } \\ \text { HDL } & \text { glycated hemoglobin } \\ \text { HF } & \text { high-density lipoprotein } \\ \text { HFD } & \text { high fat } \\ \text { HOMA-IR } & \text { homeostatic model assessment of insulin resistance } \\ \text { HPFS } & \text { IAUC } \\ \text { ICAM-1 } & \end{array}$




\begin{tabular}{|c|c|}
\hline IGT & impaired glucose tolerance \\
\hline IL-6 & interleukin-6 \\
\hline IR & insulin resistance \\
\hline LDL & low-density lipoprotein \\
\hline LF & low-fat \\
\hline LPS & lipopolysaccharide \\
\hline MedDiet & Mediterranean diet \\
\hline MESA & Multi-Ethnic Study of Atherosclerosis \\
\hline MetS & metabolic syndrome \\
\hline MI & myocardial infarction \\
\hline miRNA and miR & microRNA \\
\hline $\mathrm{M} / \mathrm{F}$ & male/female \\
\hline MUFA & monounsaturated fatty acids \\
\hline NA & not available \\
\hline NAFLD & non-alcoholic fatty liver disease \\
\hline NCEP & National Cholesterol Education Program \\
\hline NHANES & National Health and Nutrition Examination Survey \\
\hline NHS & Nurses' Health Study \\
\hline NLCS & Netherlands Cohort Study \\
\hline NS & non-significant \\
\hline $\mathrm{Ob}$ & obese \\
\hline ORAC & oxygen radical absorbance capacity \\
\hline Ow & overweight \\
\hline PBMC & peripheral blood mononuclear cell \\
\hline PF-4 & platelet factor- 4 \\
\hline PHS & Physicians' Health Study \\
\hline PM & post-menopausal \\
\hline PPAR & peroxisome proliferator-activated receptors \\
\hline pre-D & pre-diabetes \\
\hline PREDIMED & PREvención con DIeta MEDiterránea \\
\hline PUFA & polyunsaturated fatty acids \\
\hline PWE & polyphenol-rich walnut extract \\
\hline $\operatorname{Re}$ & range \\
\hline RETN & resistin \\
\hline $\mathrm{RCT}$ & randomized clinical trial \\
\hline RGR & relative glycaemic responses \\
\hline RR & relative risk \\
\hline RW & red wine \\
\hline ROS & reactive oxygen species \\
\hline S & sedentary \\
\hline SBP & systolic blood pressure \\
\hline SCCS & Southern Community Cohort Study \\
\hline SCFA & short chain fatty acids \\
\hline SFA & saturated fatty acids \\
\hline SLC2A4 & solute carrier family 2 member 4 \\
\hline SMHS & Shanghai Men's Health Study \\
\hline STZ & streptozotocin \\
\hline SWHS & Shanghai Women's Health Study \\
\hline $\mathrm{T} 2 \mathrm{D}$ & type 2 diabetes \\
\hline $\mathrm{TC}$ & total cholesterol \\
\hline $\mathrm{TF}$ & tissue factor \\
\hline TG & triglycerides \\
\hline TLGS & Tehran Lipid and Glucose Study \\
\hline TNF- $\alpha$ & tumor necrosis factor- $\alpha$ \\
\hline USDA & United States Department of Agriculture \\
\hline VFM & visceral fat mass \\
\hline WB & white bread \\
\hline WC & waist circumference \\
\hline$W H t R$ & waist-to-height ratio \\
\hline
\end{tabular}




\section{References}

1. Widmer, R.J.; Flammer, A.J.; Lerman, L.O.; Lerman, A. The Mediterranean diet, its components, and cardiovascular disease. Am. J. Med. 2015, 128, 229-238. [CrossRef] [PubMed]

2. Ros, E. Health Benefits of Nut Consumption. Nutrients 2010, 2, 652-682. [CrossRef] [PubMed]

3. Chang, S.K.; Alasalvar, C.; Shahidi, F. Review of dried fruits: Phytochemicals, antioxidant efficacies, and health benefits. J. Funct. Foods 2016, 21, 113-132. [CrossRef]

4. Ros, E. Nuts and CVD. Br. J. Nutr. 2015, 113 (Suppl.), S111-S120. [CrossRef] [PubMed]

5. Casas-Agustench, P.; Salas-Huetos, A.; Salas-Salvadó, J. Mediterranean nuts: Origins, ancient medicinal benefits and symbolism. Public Health Nutr. 2011, 14, 2296-2301. [CrossRef] [PubMed]

6. Salas-Salvadó, J.; Casas-Agustench, P.; Salas-Huetos, A. Cultural and historical aspects of Mediterranean nuts with emphasis on their attributed healthy and nutritional properties. Nutr. Metab. Cardiovasc. Dis. 2011, 21 (Suppl. 1), S1-S6. [CrossRef] [PubMed]

7. Sofi, F. The Mediterranean diet revisited: Evidence of its effectiveness grows. Curr. Opin. Cardiol. 2009, 24, 442-446. [CrossRef] [PubMed]

8. Alasalvar, C.; Shahidi, F. Composition, phytochemicals, and beneficial health effects of dried fruits: An overview. In Dried Fruits: Phytochemicals and Health Effects; Wiley-Blackwell: Oxford, UK, 2013; pp. 372-392.

9. US Department of Agriculture, Agricultural Research Service, Nutrient Data Laboratory. USDA National Nutrient Database for Standard Reference, Release 28 (revised), Version Current: May 2015. Available online: http:/ / www.ars.usda.gov/ba/bhnrc/ndl (accessed on 3 March 2017).

10. Halvorsen, B.L.; Carlsen, M.H.; Phillips, K.M.; Bøhn, S.K.; Holte, K.; Jacobs, D.R.; Blomhoff, R. Content of redox-active compounds (ie, antioxidants) in foods consumed in the United States. Am. J. Clin. Nutr. 2006, 84, 95-135. [PubMed]

11. Phillips, K.M.; Ruggio, D.M.; Ashraf-Khorassani, M. Phytosterol composition of nuts and seeds commonly consumed in the United States. J. Agric. Food Chem. 2005, 53, 9436-9445. [CrossRef] [PubMed]

12. Montonen, J.; Knekt, P.; Jarvinen, R.; Reunanen, A. Dietary Antioxidant Intake and Risk of Type 2 Diabetes. Diabetes Care 2004, 27, 362-366. [CrossRef] [PubMed]

13. Sluijs, I.; Cadier, E.; Beulens, J.W.J.; van der A, D.L.; Spijkerman, A.M.W.; van der Schouw, Y.T. Dietary intake of carotenoids and risk of type 2 diabetes. Nutr. Metab. Cardiovasc. Dis. 2015, 25, 376-381. [CrossRef] [PubMed]

14. Zhao, B.; Hall, C.A. Composition and antioxidant activity of raisin extracts obtained from various solvents. Food Chem. 2008, 108, 511-518. [CrossRef] [PubMed]

15. Anderson, J.W.; Waters, A.R. Raisin consumption by humans: Effects on glycemia and insulinemia and cardiovascular risk factors. J. Food Sci. 2013, 78, A11-A17. [CrossRef] [PubMed]

16. Mandalari, G.; Bisignano, C.; Filocamo, A.; Chessa, S.; Sarò, M.; Torre, G.; Faulks, R.M.; Dugo, P. Bioaccessibility of pistachio polyphenols, xanthophylls, and tocopherols during simulated human digestion. Nutrition 2013, 29, 338-344. [CrossRef] [PubMed]

17. O'Neil, C.E.; Keast, D.R.; Fulgoni, V.L.; Nicklas, T.A. Tree nut consumption improves nutrient intake and diet quality in US adults: An analysis of national health and nutrition examination survey (NHANES) 1999-2004. Asia Pac. J. Clin. Nutr. 2010, 19, 142-150. [PubMed]

18. O'Neil, C.E.; Keast, D.R.; Nicklas, T.A.; Fulgoni, V.L. Out-of-hand nut consumption is associated with improved nutrient intake and health risk markers in US children and adults: National Health and Nutrition Examination Survey 1999-2004. Nutr. Res. 2012, 32, 185-194. [CrossRef] [PubMed]

19. Tey, S.L.; Brown, R.; Gray, A.; Chisholm, A.; Delahunty, C. Nuts improve diet quality compared to other energy-dense snacks while maintaining body weight. J. Nutr. Metab. 2011, 2011, 357350. [CrossRef] [PubMed]

20. McManus, K.; Antinoro, L.; Sacks, F. A randomized controlled trial of a moderate-fat, low-energy diet compared with a low fat, low-energy diet for weight loss in overweight adults. Int. J. Obes. Relat. Metab. Disord. 2001, 25, 1503-1511. [CrossRef] [PubMed]

21. Bazzano, L.A.; Li, T.Y.; Joshipura, K.J.; Hu, F.B. Intake of fruit, vegetables, and fruit juices and risk of diabetes in women. Diabetes Care 2008, 31, 1311-1317. [CrossRef] [PubMed] 
22. Keast, D.R.; O'Neil, C.E.; Jones, J.M. Dried fruit consumption is associated with improved diet quality and reduced obesity in US adults: National Health and Nutrition Examination Survey, 1999-2004. Nutr. Res. 2011, 31, 460-467. [CrossRef] [PubMed]

23. Chan, R.; Wong, V.W.-S.; Chu, W.C.-W.; Wong, G.L.-H.; Li, L.S.; Leung, J.; Chim, A.M.-L.; Yeung, D.K.-W.; Sea, M.M.-M.; Woo, J.; et al. Diet-Quality Scores and Prevalence of Nonalcoholic Fatty Liver Disease: A Population Study Using Proton-Magnetic Resonance Spectroscopy. PLoS ONE 2015, 10, e0139310. [CrossRef] [PubMed]

24. U.S. Department of Health and Human Services and U.S. Department of Agriculture. 2015-2020 Dietary Guidelines for Americans, 8th Edition edDecember 2015. Available online: http://health.gov/ dietaryguidelines/2015/guidelines/ (accessed on 10 March 2017).

25. Bilbis, L.S.; Shehu, R.A.; Abubakar, M.G. Hypoglycemic and hypolipidemic effects of aqueous extract of Arachis hypogaea in normal and alloxan-induced diabetic rats. Phytomedicine 2002, 9, 553-555. [CrossRef] [PubMed]

26. Fukuda, T.; Ito, H.; Yoshida, T. Effect of the walnut polyphenol fraction on oxidative stress in type 2 diabetes mice. Biofactors 2004, 21, 251-253. [CrossRef] [PubMed]

27. Ramesh, B.; Saravanan, R.; Pugalendi, K. V Effect of dietary substitution of groundnut oil on blood glucose, lipid profile, and redox status in streptozotocin-diabetic rats. Yale J. Biol. Med. 2006, 79, 9-17. [PubMed]

28. Emekli-Alturfan, E.; Kasikci, E.; Yarat, A. Tissue factor activities of streptozotocin induced diabetic rat tissues and the effect of peanut consumption. Diabetes Metab. Res. Rev. 2007, 23, 653-658. [CrossRef] [PubMed]

29. Choi, Y.; Abdelmegeed, M.A.; Akbar, M.; Song, B.-J.J. Dietary walnut reduces hepatic triglyceride content in high-fat-fed mice via modulation of hepatic fatty acid metabolism and adipose tissue inflammation. J. Nutr. Biochem. 2016, 30, 116-125. [CrossRef] [PubMed]

30. Overman, A.; Bumrungpert, A.; Kennedy, A.; Martinez, K.; Chuang, C.-C.; West, T.; Dawson, B.; Jia, W.; McIntosh, M. Polyphenol-rich grape powder extract (GPE) attenuates inflammation in human macrophages and in human adipocytes exposed to macrophage-conditioned media. Int. J. Obes. (Lond.) 2010, 34, 800-808. [CrossRef] [PubMed]

31. Chuang, C.-C.; Bumrungpert, A.; Kennedy, A.; Overman, A.; West, T.; Dawson, B.; McIntosh, M.K. Grape powder extract attenuates tumor necrosis factor $\alpha$-mediated inflammation and insulin resistance in primary cultures of human adipocytes. J. Nutr. Biochem. 2011, 22, 89-94. [CrossRef] [PubMed]

32. Chuang, C.-C.; Martinez, K.; Xie, G.; Kennedy, A.; Bumrungpert, A.; Overman, A.; Jia, W.; McIntosh, M.K. Quercetin is equally or more effective than resveratrol in attenuating tumor necrosis factor-Mediated inflammation and insulin resistance in primary human adipocytes. Am. J. Clin. Nutr. 2010, 92, 1511-1521. [CrossRef] [PubMed]

33. Zangiabadi, N.; Asadi-Shekaari, M.; Sheibani, V.; Jafari, M.; Shabani, M.; Asadi, A.R.; Tajadini, H.; Jarahi, M. Date fruit extract is a neuroprotective agent in diabetic peripheral neuropathy in streptozotocin-induced diabetic rats: A multimodal analysis. Oxid. Med. Cell. Longev. 2011, 2011, 976948. [CrossRef] [PubMed]

34. Porto, L.C.S.; da Silva, J.; Ferraz, A.B.F.; Ethur, E.M.; Porto, C.D.L.; Marroni, N.P.; Picada, J.N. The Antidiabetic and Antihypercholesterolemic Effects of an Aqueous Extract from Pecan Shells in Wistar Rats. Plant Foods Hum. Nutr. 2015, 70, 414-419. [CrossRef] [PubMed]

35. Tédong, L.; Dzeufiet, P.D.D.; Dimo, T.; Asongalem, E.A.; Sokeng, S.N.; Flejou, J.-F.; Callard, P.; Kamtchouing, P. Acute and subchronic toxicity of Anacardium occidentale Linn (Anacardiaceae) leaves hexane extract in mice. Afr. J. Tradit. Complement. Altern. Med. AJTCAM 2006, 4, 140-147. [CrossRef] [PubMed]

36. Asgary, S.; Parkhideh, S.; Solhpour, A.; Madani, H.; Mahzouni, P.; Rahimi, P. Effect of ethanolic extract of Juglans regia L. on blood sugar in diabetes-induced rats. J. Med. Food 2008, 11, 533-538. [CrossRef] [PubMed]

37. Ojewole, J.A.O. Laboratory evaluation of the hypoglycemic effect of Anacardium occidentale Linn (Anacardiaceae) stem-bark extracts in rats. Methods Find. Exp. Clin. Pharmacol. 2003, 25, 199-204. [CrossRef] [PubMed]

38. Egwim, E. Hypoglycemic potencies of crude ethanolic extracts of cashew roots and unripe pawpaw fruits in guinea pigs and rats. J. Herb. Pharmacother. 2005, 5, 27-34. [CrossRef] [PubMed]

39. Jelodar, G.; Mohsen, M.; Shahram, S. Effect of walnut leaf, coriander and pomegranate on blood glucose and histopathology of pancreas of alloxan induced diabetic rats. Afr. J. Tradit. Complement. Altern. Med. AJTCAM 2007, 4, 299-305. [CrossRef] [PubMed] 
40. Eid, H.M.; Martineau, L.C.; Saleem, A.; Muhammad, A.; Vallerand, D.; Benhaddou-Andaloussi, A.; Nistor, L.; Afshar, A.; Arnason, J.T.; Haddad, P.S. Stimulation of AMP-activated protein kinase and enhancement of basal glucose uptake in muscle cells by quercetin and quercetin glycosides, active principles of the antidiabetic medicinal plant Vaccinium vitis-idaea. Mol. Nutr. Food Res. 2010, 54, 991-1003. [CrossRef] [PubMed]

41. Vassiliou, E.K.; Gonzalez, A.; Garcia, C.; Tadros, J.H.; Chakraborty, G.; Toney, J.H. Oleic acid and peanut oil high in oleic acid reverse the inhibitory effect of insulin production of the inflammatory cytokine TNF-alpha both in vitro and in vivo systems. Lipids Health Dis. 2009, 8, 25. [CrossRef] [PubMed]

42. Adewale, O.F.; Isaac, O.; Tunmise, M.T.; Omoniyi, O. Palm oil and ground nut oil supplementation effects on blood glucose and antioxidant status in alloxan-induced diabetic rats. Pak. J. Pharm. Sci. 2016, 29, 83-87. [PubMed]

43. Anderson, K.J.; Teuber, S.S.; Gobeille, A.; Cremin, P.; Waterhouse, A.L.; Steinberg, F.M. Walnut polyphenolics inhibit in vitro human plasma and LDL oxidation. J. Nutr. 2001, 131, 2837-2842. [PubMed]

44. Chen, C.-Y.; Milbury, P.E.; Lapsley, K.; Blumberg, J.B. Flavonoids from almond skins are bioavailable and act synergistically with vitamins $\mathrm{C}$ and $\mathrm{E}$ to enhance hamster and human LDL resistance to oxidation. J. Nutr. 2005, 135, 1366-1373. [PubMed]

45. Wijeratne, S.S.K.; Abou-Zaid, M.M.; Shahidi, F. Antioxidant polyphenols in almond and its coproducts. J. Agric. Food Chem. 2006, 54, 312-318. [CrossRef] [PubMed]

46. Gentile, C.; Tesoriere, L.; Butera, D.; Fazzari, M.; Monastero, M.; Allegra, M.; Livrea, M.A. Antioxidant activity of Sicilian pistachio (Pistacia vera L Var. Bronte) nut extract and its bioactive components. J. Agric. Food Chem. 2007, 55, 643-648. [CrossRef] [PubMed]

47. Shahidi, F.; Alasalvar, C.; Liyana-Pathirana, C.M. Antioxidant phytochemicals in hazelnut kernel (Corylus avellana L) and hazelnut byproducts. J. Agric. Food Chem. 2007, 55, 1212-1220. [CrossRef] [PubMed]

48. Tedong, L.; Madiraju, P.; Martineau, L.C.; Vallerand, D.; Arnason, J.T.; Desire, D.D.P.; Lavoie, L.; Kamtchouing, P.; Haddad, P.S. Hydro-ethanolic extract of cashew tree (Anacardium occidentale) nut and its principal compound, anacardic acid, stimulate glucose uptake in C2C12 muscle cells. Mol. Nutr. Food Res. 2010, 54, 1753-1762. [CrossRef] [PubMed]

49. Shahraki, J.; Zareh, M.; Kamalinejad, M.; Pourahmad, J. Cytoprotective Effects of Hydrophilic and Lipophilic Extracts of Pistacia vera against Oxidative Versus Carbonyl Stress in Rat Hepatocytes. Iran. J. Pharm. Res. IJPR 2014, 13, 1263-1277. [PubMed]

50. Aoun, M.; Michel, F.; Fouret, G.; Schlernitzauer, A.; Ollendorff, V.; Wrutniak-Cabello, C.; Cristol, J.-P.; Carbonneau, M.-A.; Coudray, C.; Feillet-Coudray, C. A grape polyphenol extract modulates muscle membrane fatty acid composition and lipid metabolism in high-fat-high-sucrose diet-fed rats. Br. J. Nutr. 2011, 106, 491-501. [CrossRef] [PubMed]

51. Weijers, R.N.M. Lipid composition of cell membranes and its relevance in type 2 diabetes mellitus. Curr. Diabetes Rev. 2012, 8, 390-400. [CrossRef] [PubMed]

52. Soares de Moura, R.; da Costa, G.F.; Moreira, A.S.B.; Queiroz, E.F.; Moreira, D.D.C.; Garcia-Souza, E.P.; Resende, A.C.; Moura, A.S.; Teixeira, M.T. Vitis vinifera L. grape skin extract activates the insulin-signalling cascade and reduces hyperglycaemia in alloxan-induced diabetic mice. J. Pharm. Pharmacol. 2012, 64, 268-276. [CrossRef] [PubMed]

53. Adam, S.H.; Giribabu, N.; Kassim, N.; Kumar, K.E.; Brahmayya, M.; Arya, A.; Salleh, N. Protective effect of aqueous seed extract of Vitis Vinifera against oxidative stress, inflammation and apoptosis in the pancreas of adult male rats with diabetes mellitus. Biomed. Pharmacother. 2016, 81, 439-452. [CrossRef] [PubMed]

54. Esposito, D.; Damsud, T.; Wilson, M.; Grace, M.H.; Strauch, R.; Li, X.; Lila, M.A.; Komarnytsky, S. Black Currant Anthocyanins Attenuate Weight Gain and Improve Glucose Metabolism in Diet-Induced Obese Mice with Intact, but Not Disrupted, Gut Microbiome. J. Agric. Food Chem. 2015, 63, 6172-6180. [CrossRef] [PubMed]

55. Schmatz, R.; Mann, T.R.; Spanevello, R.; Machado, M.M.; Zanini, D.; Pimentel, V.C.; Stefanello, N.; Martins, C.C.; Cardoso, A.M.; Bagatini, M.; et al. Moderate red wine and grape juice consumption modulates the hydrolysis of the adenine nucleotides and decreases platelet aggregation in streptozotocin-induced diabetic rats. Cell Biochem. Biophys. 2013, 65, 129-143. [CrossRef] [PubMed] 
56. Hernández-Salinas, R.; Decap, V.; Leguina, A.; Cáceres, P.; Perez, D.; Urquiaga, I.; Iturriaga, R.; Velarde, V. Antioxidant and anti hyperglycemic role of wine grape powder in rats fed with a high fructose diet. Biol. Res. 2015, 48, 53. [CrossRef] [PubMed]

57. Overman, A.; Chuang, C.-C.; McIntosh, M. Quercetin attenuates inflammation in human macrophages and adipocytes exposed to macrophage-conditioned media. Int. J. Obes. (Lond.) 2011, 35, 1165-1172. [CrossRef] [PubMed]

58. Nettleton, J.A.; Steffen, L.M.; Ni, H.; Liu, K.; Jacobs, D.R. Dietary patterns and risk of incident type 2 diabetes in the Multi-Ethnic Study of Atherosclerosis (MESA). Diabetes Care 2008, 31, 1777-1782. [CrossRef] [PubMed]

59. O'Neil, C.E.; Fulgoni, V.L.; Nicklas, T.A. Tree Nut consumption is associated with better adiposity measures and cardiovascular and metabolic syndrome health risk factors in U.S. Adults: NHANES 2005-2010. Nutr. J. 2015, 14, 64. [CrossRef] [PubMed]

60. Asghari, G.; Ghorbani, Z.; Mirmiran, P.; Azizi, F. Nut consumption is associated with lower incidence of type 2 diabetes: The Tehran Lipid and Glucose Study. Diabetes Metab. 2017, 43, 18-24. [CrossRef] [PubMed]

61. Jiang, R.; Manson, J.E.; Stampfer, M.J.; Liu, S.; Willett, W.C.; Hu, F.B. Nut and peanut butter consumption and risk of type 2 diabetes in women. JAMA 2002, 288, 2554-2560. [CrossRef] [PubMed]

62. Villegas, R.; Gao, Y.-T.T.; Yang, G.; Li, H.-L.L.; Elasy, T.A.; Zheng, W.; Shu, X.O. Legume and soy food intake and the incidence of type 2 diabetes in the Shanghai Women's Health Study. Am. J. Clin. Nutr. 2008, 87, 162-167. [PubMed]

63. Ibarrola-Jurado, N.; Bulló, M.; Guasch-Ferré, M.; Ros, E.; Martínez-González, M.A.; Corella, D.; Fiol, M.; Wärnberg, J.; Estruch, R.; Román, P.; et al. Cross-sectional assessment of nut consumption and obesity, metabolic syndrome and other cardiometabolic risk factors: The PREDIMED study. PLoS ONE 2013, 8, e57367. [CrossRef] [PubMed]

64. Pan, A.; Sun, Q.; Manson, J.E.; Willett, W.C.; Hu, F.B. Walnut consumption is associated with lower risk of type 2 diabetes in women. J. Nutr. 2013, 143, 512-518. [CrossRef] [PubMed]

65. van den Brandt, P.A.; Schouten, L.J. Relationship of tree nut, peanut and peanut butter intake with total and cause-specific mortality: A cohort study and meta-analysis. Int. J. Epidemiol. 2015, 44, 1038-1049. [CrossRef] [PubMed]

66. Buijsse, B.; Boeing, H.; Drogan, D.; Schulze, M.B.; Feskens, E.J.; Amiano, P.; Barricarte, A.; Clavel-Chapelon, F.; de Lauzon-Guillain, B.; Fagherazzi, G.; et al. Consumption of fatty foods and incident type 2 diabetes in populations from eight European countries. Eur. J. Clin. Nutr. 2015, 69, 455-461. [CrossRef] [PubMed]

67. Kochar, J.; Gaziano, J.M.; Djoussé, L. Nut consumption and risk of type II diabetes in the Physicians' Health Study. Eur. J. Clin. Nutr. 2010, 64, 75-79. [CrossRef] [PubMed]

68. Pimpin, L.; Wu, J.H.Y.; Haskelberg, H.; Del Gobbo, L.; Mozaffarian, D. Is Butter Back? A Systematic Review and Meta-Analysis of Butter Consumption and Risk of Cardiovascular Disease, Diabetes, and Total Mortality. PLoS ONE 2016, 11, e0158118. [CrossRef] [PubMed]

69. Jenkins, D.J.A.; Kendall, C.W.C.; Josse, A.R.; Salvatore, S.; Brighenti, F.; Augustin, L.S.A.; Ellis, P.R.; Vidgen, E.; Rao, A.V. Almonds Decrease Postprandial Glycemia, Insulinemia, and Oxidative Damage in Healthy Individuals. J. Nutr. 2006, 136, 2987-2992. [PubMed]

70. Josse, A.R.; Kendall, C.W.C.; Augustin, L.S.A.; Ellis, P.R.; Jenkins, D.J.A. Almonds and postprandial glycemia-A dose-response study. Metabolism. 2007, 56, 400-404. [CrossRef] [PubMed]

71. Mori, A.M.; Considine, R.V.; Mattes, R.D.; Wong, J.; Jenkins, D.; Jiang, R.; Manson, J.; Stampfer, M.; Liu, S.; Willett, W.; et al. Acute and second-meal effects of almond form in impaired glucose tolerant adults: A randomized crossover trial. Nutr. Metab. (Lond.) 2011, 8, 6. [CrossRef] [PubMed]

72. Cohen, A.E.; Johnston, C.S. Almond ingestion at mealtime reduces postprandial glycemia and chronic ingestion reduces hemoglobin A1c in individuals with well-controlled type 2 diabetes mellitus. Metabolism 2011, 60, 1312-1317. [CrossRef] [PubMed]

73. Crouch, M.A.; Slater, R.T. Almond "Appetizer" Effect on Glucose Tolerance Test (GTT) Results. J. Am. Board Fam. Med. 2016, 29, 759-766. [CrossRef] [PubMed]

74. Kendall, C.W.C.; Josse, A.R.; Esfahani, A.; Jenkins, D.J.A. The impact of pistachio intake alone or in combination with high-carbohydrate foods on post-prandial glycemia. Eur. J. Clin. Nutr. 2011, 65, 696-702. [CrossRef] [PubMed] 
75. Kendall, C.W.C.; West, S.G.; Augustin, L.S.; Esfahani, A.; Vidgen, E.; Bashyam, B.; Sauder, K.A.; Campbell, J.; Chiavaroli, L.; Jenkins, A.L.; et al. Acute effects of pistachio consumption on glucose and insulin, satiety hormones and endothelial function in the metabolic syndrome. Eur. J. Clin. Nutr. 2014, 68, 370-375. [CrossRef] [PubMed]

76. Reis, C.E.G.; Bordalo, L.A.; Rocha, A.L.C.; Freitas, D.M.O.; da Silva, M.V.L.; de Faria, V.C.; Martino, H.S.D.; Costa, N.M.B.; Alfenas, R.C. Ground roasted peanuts leads to a lower post-prandial glycemic response than raw peanuts. Nutr. Hosp. 2011, 26, 745-751. [PubMed]

77. Moreira, A.P.B.; Teixeira, T.F.S.; Alves, R.D.M.; Peluzio, M.C.G.; Costa, N.M.B.; Bressan, J.; Mattes, R.; Alfenas, R.C.G. Effect of a high-fat meal containing conventional or high-oleic peanuts on post-prandial lipopolysaccharide concentrations in overweight/obese men. J. Hum. Nutr. Diet. 2016, 29, 95-104. [CrossRef] [PubMed]

78. Kendall, C.W.C.; Esfahani, A.; Josse, A.R.; Augustin, L.S.A.; Vidgen, E.; Jenkins, D.J.A. The glycemic effect of nut-enriched meals in healthy and diabetic subjects. Nutr. Metab. Cardiovasc. Dis. 2011, 21 (Suppl. 1), S34-S39. [CrossRef] [PubMed]

79. Lovejoy, J.C.; Most, M.M.; Lefevre, M.; Greenway, F.L.; Rood, J.C. Effect of diets enriched in almonds on insulin action and serum lipids in adults with normal glucose tolerance or type 2 diabetes. Am. J. Clin. Nutr. 2002, 76, 1000-1006. [PubMed]

80. Li, S.-C.; Liu, Y.-H.; Liu, J.-F.; Chang, W.-H.; Chen, C.-M.; Chen, C.-Y.O. Almond consumption improved glycemic control and lipid profiles in patients with type 2 diabetes mellitus. Metabolism 2011, 60, 474-479. [CrossRef] [PubMed]

81. Damavandi, R.D.; Eghtesadi, S.; Shidfar, F.; Heydari, I.; Foroushani, A.R. Effects of hazelnuts consumption on fasting blood sugar and lipoproteins in patients with type 2 diabetes. J. Res. Med. Sci. 2013, 18, 314-321. [PubMed]

82. Lasa, A.; Miranda, J.; Bulló, M.; Casas, R.; Salas-Salvadó, J.; Larretxi, I.; Estruch, R.; Ruiz-Gutiérrez, V.; Portillo, M.P. Comparative effect of two Mediterranean diets versus a low-fat diet on glycaemic control in individuals with type 2 diabetes. Eur. J. Clin. Nutr. 2014, 68, 767-772. [CrossRef] [PubMed]

83. Parham, M.; Heidari, S.; Khorramirad, A.; Hozoori, M.; Hosseinzadeh, F.; Bakhtyari, L.; Vafaeimanesh, J. Effects of pistachio nut supplementation on blood glucose in patients with type 2 diabetes: A randomized crossover trial. Rev. Diabet. Stud. 2014, 11, 190-196. [CrossRef] [PubMed]

84. Gulati, S.; Misra, A.; Pandey, R.M. Effect of Almond Supplementation on Glycemia and Cardiovascular Risk Factors in Asian Indians in North India with Type 2 Diabetes Mellitus: A 24-Week Study. Metab. Syndr. Relat. Disord. 2017, 15, 98-105. [CrossRef] [PubMed]

85. Hernández-Alonso, P.; Salas-Salvadó, J.; Baldrich-Mora, M.; Juanola-Falgarona, M.; Bulló, M. Beneficial Effect of Pistachio Consumption on Glucose Metabolism, Insulin Resistance, Inflammation, and Related Metabolic Risk Markers: A Randomized Clinical Trial. Diabetes Care 2014, 37, 3098-3105. [CrossRef] [PubMed]

86. Jenkins, D.J.A.; Kendall, C.W.C.; Marchie, A.; Josse, A.R.; Nguyen, T.H.; Faulkner, D.A.; Lapsley, K.G.; Singer, W. Effect of almonds on insulin secretion and insulin resistance in nondiabetic hyperlipidemic subjects: A randomized controlled crossover trial. Metabolism 2008, 57, 882-887. [CrossRef] [PubMed]

87. Le, T.; Flatt, S.W.; Natarajan, L.; Pakiz, B.; Quintana, E.L.; Heath, D.D.; Rana, B.K.; Rock, C.L. Effects of Diet Composition and Insulin Resistance Status on Plasma Lipid Levels in a Weight Loss Intervention in Women. J. Am. Heart Assoc. 2016, 5, e002771. [CrossRef] [PubMed]

88. Claesson, A.-L.; Holm, G.; Ernersson, A.; Lindström, T.; Nystrom, F.H. Two weeks of overfeeding with candy, but not peanuts, increases insulin levels and body weight. Scand. J. Clin. Lab. Invest. 2009, 69, 598-605. [CrossRef] [PubMed]

89. Wien, M.A.; Sabaté, J.M.; Iklé, D.N.; Cole, S.E.; Kandeel, F.R. Almonds vs. complex carbohydrates in a weight reduction program. Int. J. Obes. Relat. Metab. Disord. 2003, 27, 1365-1372. [CrossRef] [PubMed]

90. Esposito, K.; Marfella, R.; Ciotola, M.; Di Palo, C.; Giugliano, F.; Giugliano, G.; D’Armiento, M.; D’Andrea, F.; Giugliano, D. Effect of a mediterranean-style diet on endothelial dysfunction and markers of vascular inflammation in the metabolic syndrome: A randomized trial. JAMA 2004, 292, 1440-1446. [CrossRef] [PubMed]

91. Tapsell, L.C.; Gillen, L.J.; Patch, C.S.; Batterham, M.; Owen, A.; Baré, M.; Kennedy, M. Including walnuts in a low-fat/modified-fat diet improves HDL cholesterol-to-total cholesterol ratios in patients with type 2 diabetes. Diabetes Care 2004, 27, 2777-2783. [CrossRef] [PubMed] 
92. Tapsell, L.C.; Batterham, M.J.; Teuss, G.; Tan, S.-Y.; Dalton, S.; Quick, C.J.; Gillen, L.J.; Charlton, K.E. Long-term effects of increased dietary polyunsaturated fat from walnuts on metabolic parameters in type II diabetes. Eur. J. Clin. Nutr. 2009, 63, 1008-1015. [CrossRef] [PubMed]

93. Ma, Y.; Njike, V.Y.; Millet, J.; Dutta, S.; Doughty, K.; Treu, J.A.; Katz, D.L. Effects of walnut consumption on endothelial function in type 2 diabetic subjects: A randomized controlled crossover trial. Diabetes Care 2010, 33, 227-232. [CrossRef] [PubMed]

94. Brennan, A.M.; Sweeney, L.L.; Liu, X.; Mantzoros, C.S. Walnut consumption increases satiation but has no effect on insulin resistance or the metabolic profile over a 4-day period. Obesity (Silver Spring) 2010, 18, 1176-1182. [CrossRef] [PubMed]

95. Wang, X.; Li, Z.; Liu, Y.; Lv, X.; Yang, W. Effects of pistachios on body weight in Chinese subjects with metabolic syndrome. Nutr. J. 2012, 11, 20. [CrossRef] [PubMed]

96. Katz, D.L.; Davidhi, A.; Ma, Y.; Kavak, Y.; Bifulco, L.; Njike, V.Y. Effects of walnuts on endothelial function in overweight adults with visceral obesity: A randomized, controlled, crossover trial. J. Am. Coll. Nutr. 2012, 31, 415-423. [CrossRef] [PubMed]

97. Richmond, K.; Williams, S.; Mann, J.; Brown, R.; Chisholm, A. Markers of Cardiovascular Risk in Postmenopausal Women with Type 2 Diabetes Are Improved by the Daily Consumption of Almonds or Sunflower Kernels: A Feeding Study. ISRN Nutr. 2013, 2013, 1-9. [CrossRef] [PubMed]

98. Tan, S.Y.; Mattes, R.D. Appetitive, dietary and health effects of almonds consumed with meals or as snacks: A randomized, controlled trial. Eur. J. Clin. Nutr. 2013, 67, 1205-1214. [CrossRef] [PubMed]

99. Liu, J.-F.; Liu, Y.-H.; Chen, C.-M.; Chang, W.-H.; Chen, C.-Y.O. The effect of almonds on inflammation and oxidative stress in Chinese patients with type 2 diabetes mellitus: A randomized crossover controlled feeding trial. Eur. J. Nutr. 2013, 52, 927-935. [CrossRef] [PubMed]

100. Wu, L.; Piotrowski, K.; Rau, T.; Waldmann, E.; Broedl, U.C.; Demmelmair, H.; Koletzko, B.; Stark, R.G.; Nagel, J.M.; Mantzoros, C.S.; et al. Walnut-enriched diet reduces fasting non-HDL-cholesterol and apolipoprotein B in healthy Caucasian subjects: A randomized controlled cross-over clinical trial. Metabolism 2014, 63, 382-391. [CrossRef] [PubMed]

101. Wien, M.; Oda, K.; Sabaté, J. A randomized controlled trial to evaluate the effect of incorporating peanuts into an American Diabetes Association meal plan on the nutrient profile of the total diet and cardiometabolic parameters of adults with type 2 diabetes. Nutr. J. 2014, 13, 10. [CrossRef] [PubMed]

102. Sauder, K.A.; McCrea, C.E.; Ulbrecht, J.S.; Kris-Etherton, P.M.; West, S.G. Effects of pistachios on the lipid/lipoprotein profile, glycemic control, inflammation, and endothelial function in type 2 diabetes: A randomized trial. Metabolism 2015, 64, 1521-1529. [CrossRef] [PubMed]

103. Njike, V.Y.; Ayettey, R.; Petraro, P.; Treu, J.A.; Katz, D.L. Walnut ingestion in adults at risk for diabetes: Effects on body composition, diet quality, and cardiac risk measures. BMJ Open Diabetes Res. Care 2015, 3, e000115. [CrossRef] [PubMed]

104. Sari, I.; Baltaci, Y.; Bagci, C.; Davutoglu, V.; Erel, O.; Celik, H.; Ozer, O.; Aksoy, N.; Aksoy, M. Effect of pistachio diet on lipid parameters, endothelial function, inflammation, and oxidative status: A prospective study. Nutrition 2010, 26, 399-404. [CrossRef] [PubMed]

105. Gulati, S.; Misra, A.; Pandey, R.M.; Bhatt, S.P.; Saluja, S. Effects of pistachio nuts on body composition, metabolic, inflammatory and oxidative stress parameters in Asian Indians with metabolic syndrome: A 24-week, randomized control trial. Nutrition 2014, 30, 192-197. [CrossRef] [PubMed]

106. Wien, M.; Bleich, D.; Raghuwanshi, M.; Gould-Forgerite, S.; Gomes, J.; Monahan-Couch, L.; Oda, K. Almond consumption and cardiovascular risk factors in adults with prediabetes. J. Am. Coll. Nutr. 2010, 29, 189-197. [CrossRef] [PubMed]

107. Casas-Agustench, P.; López-Uriarte, P.; Bulló, M.; Ros, E.; Cabré-Vila, J.J.; Salas-Salvadó, J. Effects of one serving of mixed nuts on serum lipids, insulin resistance and inflammatory markers in patients with the metabolic syndrome. Nutr. Metab. Cardiovasc. Dis. 2011, 21, 126-135. [CrossRef] [PubMed]

108. Mejia, S.B.; Kendall, C.W.C.; Viguiliouk, E.; Augustin, L.S.; Ha, V.; Cozma, A.I.; Mirrahimi, A.; Maroleanu, A.; Chiavaroli, L.; Leiter, L.A.; et al. Effect of tree nuts on metabolic syndrome criteria: A systematic review and meta-analysis of randomised controlled trials. BMJ Open 2014, 4, e004660. [CrossRef] [PubMed]

109. Rasmussen, O.; Winther, E.; Hermansen, K. Postprandial glucose and insulin responses to rolled oats ingested raw, cooked or as a mixture with raisins in normal subjects and type 2 diabetic patients. Diabet. Med. 1989, 6, 337-341. [CrossRef] [PubMed] 
110. Kim, Y.; Hertzler, S.R.; Byrne, H.K.; Mattern, C.O. Raisins are a low to moderate glycemic index food with a correspondingly low insulin index. Nutr. Res. 2008, 28, 304-308. [CrossRef] [PubMed]

111. Kanellos, P.T.; Kaliora, A.C.; Liaskos, C.; Tentolouris, N.K.; Perrea, D.; Karathanos, V.T. A study of glycemic response to Corinthian raisins in healthy subjects and in type 2 diabetes mellitus patients. Plant Foods Hum. Nutr. 2013, 68, 145-148. [CrossRef] [PubMed]

112. Esfahani, A.; Lam, J.; Kendall, C.W.C. Acute effects of raisin consumption on glucose and insulin reponses in healthy individuals. J. Nutr. Sci. 2014, 3, e1. [CrossRef] [PubMed]

113. Kaliora, A.C.; Kanellos, P.T.; Gioxari, A.; Karathanos, V.T. Regulation of GIP and Ghrelin in Healthy Subjects Fed on Sun-Dried Raisins: A Pilot Study with a Crossover Trial Design. J. Med. Food 2017, 20, 301-308. [CrossRef] [PubMed]

114. Furchner-Evanson, A.; Petrisko, Y.; Howarth, L.; Nemoseck, T.; Kern, M. Type of snack influences satiety responses in adult women. Appetite 2010, 54, 564-569. [CrossRef] [PubMed]

115. Puglisi, M.J.; Vaishnav, U.; Shrestha, S.; Torres-Gonzalez, M.; Wood, R.J.; Volek, J.S.; Fernandez, M.L. Raisins and additional walking have distinct effects on plasma lipids and inflammatory cytokines. Lipids Health Dis. 2008, 7, 14. [CrossRef] [PubMed]

116. Rankin, J.W.; Andreae, M.C.; Oliver Chen, C.-Y.; O'Keefe, S.F. Effect of raisin consumption on oxidative stress and inflammation in obesity. Diabetes Obes. Metab. 2008, 10, 1086-1096. [CrossRef] [PubMed]

117. Howarth, L.; Petrisko, Y.; Furchner-Evanson, A.; Nemoseck, T.; Kern, M. Snack Selection Influences Nutrient Intake, Triglycerides, and Bowel Habits of Adult Women: A Pilot Study. J. Am. Diet. Assoc. 2010, 110, 1322-1327. [CrossRef] [PubMed]

118. Kanellos, P.T.; Kaliora, A.C.; Tentolouris, N.K.; Argiana, V.; Perrea, D.; Kalogeropoulos, N.; Kountouri, A.M.; Karathanos, V.T. A pilot, randomized controlled trial to examine the health outcomes of raisin consumption in patients with diabetes. Nutrition 2014, 30, 358-364. [CrossRef] [PubMed]

119. Bays, H.; Weiter, K.; Anderson, J. A randomized study of raisins versus alternative snacks on glycemic control and other cardiovascular risk factors in patients with type 2 diabetes mellitus. Phys. Sportsmed. 2015, 43, 37-43. [CrossRef] [PubMed]

120. Anderson, J.W.; Weiter, K.M.; Christian, A.L.; Ritchey, M.B.; Bays, H.E. Raisins Compared with Other Snack Effects on Glycemia and Blood Pressure: A Randomized, Controlled Trial. Postgrad. Med. 2014, 126, 37-43. [CrossRef] [PubMed]

121. Chandalia, M.; Garg, A.; Lutjohann, D.; von Bergmann, K.; Grundy, S.M.; Brinkley, L.J. Beneficial effects of high dietary fiber intake in patients with type 2 diabetes mellitus. N. Engl. J. Med. 2000, 342, 1392-1398. [CrossRef] [PubMed]

122. Dikeman, C.L.; Fahey, G.C. Viscosity as Related to Dietary Fiber: A Review. Crit. Rev. Food Sci. Nutr. 2006, 46, 649-663. [CrossRef] [PubMed]

123. Hopping, B.N.; Erber, E.; Grandinetti, A.; Verheus, M.; Kolonel, L.N.; Maskarinec, G. Dietary fiber, magnesium, and glycemic load alter risk of type 2 diabetes in a multiethnic cohort in Hawaii. J. Nutr. 2010, 140, 68-74. [CrossRef] [PubMed]

124. Lovejoy, J.C. The impact of nuts on diabetes and diabetes risk. Curr. Diab. Rep. 2005, 5, 379-384. [CrossRef] [PubMed]

125. Heppner, K.M.; Perez-Tilve, D. GLP-1 based therapeutics: Simultaneously combating T2DM and obesity. Front. Neurosci. 2015, 9, 92. [CrossRef] [PubMed]

126. Bodnaruc, A.M.; Prud'homme, D.; Blanchet, R.; Giroux, I. Nutritional modulation of endogenous glucagon-like peptide-1 secretion: A review. Nutr. Metab. (Lond.) 2016, 13, 92. [CrossRef] [PubMed]

127. Brand-Miller, J.; Hayne, S.; Petocz, P.; Colagiuri, S. Low-glycemic index diets in the management of diabetes: A meta-analysis of randomized controlled trials. Diabetes Care 2003, 26, 2261-2267. [CrossRef] [PubMed]

128. Mirrahimi, A.; Chiavaroli, L.; Srichaikul, K.; Augustin, L.S.A.; Sievenpiper, J.L.; Kendall, C.W.C.; Jenkins, D.J.A. The role of glycemic index and glycemic load in cardiovascular disease and its risk factors: A review of the recent literature. Curr. Atheroscler. Rep. 2014, 16, 381. [CrossRef] [PubMed]

129. Storlien, L.H.; Baur, L.A.; Kriketos, A.D.; Pan, D.A.; Cooney, G.J.; Jenkins, A.B.; Calvert, G.D.; Campbell, L. V Dietary fats and insulin action. Diabetologia 1996, 39, 621-631. [CrossRef] [PubMed]

130. Haag, M.; Dippenaar, N.G. Dietary fats, fatty acids and insulin resistance: Short review of a multifaceted connection. Med. Sci. Monit. 2005, 11, RA359-RA367. [PubMed] 
131. Risérus, U.; Willett, W.C.; Hu, F.B. Dietary fats and prevention of type 2 diabetes. Prog. Lipid Res. 2009, 48, 44-51. [CrossRef] [PubMed]

132. Segal-Isaacson, C.J.; Carello, E.; Wylie-Rosett, J. Dietary fats and diabetes mellitus: Is there a good fat? Curr. Diabetes Rep. 2001, 1, 161-169. [CrossRef]

133. Rajaram, S.; Sabaté, J. Nuts, body weight and insulin resistance. Br. J. Nutr. 2006, 96 (Suppl. 2), S79-S86. [CrossRef] [PubMed]

134. Kien, C.L. Dietary interventions for metabolic syndrome: Role of modifying dietary fats. Curr. Diabetes Rep. 2009, 9, 43-50. [CrossRef]

135. Grygiel-Górniak, B. Peroxisome proliferator-activated receptors and their ligands: Nutritional and clinical implications - a review. Nutr. J. 2014, 13, 17. [CrossRef] [PubMed]

136. Martini, L.A.; Catania, A.S.; Ferreira, S.R. Role of vitamins and minerals in prevention and management of type 2 diabetes mellitus. Nutr. Rev. 2010, 68, 341-354. [CrossRef] [PubMed]

137. Chaudhary, D.P.; Sharma, R.; Bansal, D.D. Implications of magnesium deficiency in type 2 diabetes: A review. Biol. Trace Elem. Res. 2010, 134, 119-129. [CrossRef] [PubMed]

138. Lopez-Ridaura, R.; Willett, W.C.; Rimm, E.B.; Liu, S.; Stampfer, M.J.; Manson, J.E.; Hu, F.B. Magnesium intake and risk of type 2 diabetes in men and women. Diabetes Care 2004, 27, 134-140. [CrossRef] [PubMed]

139. Guasch-Ferré, M.; Bulló, M.; Estruch, R.; Corella, D.; Martínez-González, M.A.; Ros, E.; Covas, M.; Arós, F.; Gómez-Gracia, E.; Fiol, M.; et al. Dietary magnesium intake is inversely associated with mortality in adults at high cardiovascular disease risk. J. Nutr. 2014, 144, 55-60. [CrossRef] [PubMed]

140. Pandey, K.B.; Rizvi, S.I. Current Understanding of Dietary Polyphenols and their Role in Health and Disease. Curr. Nutr. Food Sci. 2009, 5, 249-263. [CrossRef]

141. Xiao, J.B.; Högger, P. Dietary polyphenols and type 2 diabetes: Current insights and future perspectives. Curr. Med. Chem. 2015, 22, 23-38. [CrossRef] [PubMed]

142. Guo, X.; Yang, B.; Tan, J.; Jiang, J.; Li, D. Associations of dietary intakes of anthocyanins and berry fruits with risk of type 2 diabetes mellitus: A systematic review and meta-analysis of prospective cohort studies. Eur. J. Clin. Nutr. 2016, 70, 1360-1367. [CrossRef] [PubMed]

143. Oboh, G.; Ademosun, A.O.; Ogunsuyi, O.B. Quercetin and Its Role in Chronic Diseases. In Advances in Experimental Medicine and Biology; Springer Science+Business Media: Berlin/Heidelberg, Germany, 2016; Volume 929, pp. 377-387.

144. Meng, Y.; Su, A.; Yuan, S.; Zhao, H.; Tan, S.; Hu, C.; Deng, H.; Guo, Y. Evaluation of Total Flavonoids, Myricetin, and Quercetin from Hovenia dulcis Thunb. As Inhibitors of $\alpha$-Amylase and $\alpha$-Glucosidase. Plant Foods Hum. Nutr. 2016, 71, 444-449. [CrossRef] [PubMed]

145. Kang, I.; Buckner, T.; Shay, N.F.; Gu, L.; Chung, S. Improvements in Metabolic Health with Consumption of Ellagic Acid and Subsequent Conversion into Urolithins: Evidence and Mechanisms. Adv. Nutr. 2016, 7, 961-972. [CrossRef] [PubMed]

146. Yoshimura, Y.; Nishii, S.; Zaima, N.; Moriyama, T.; Kawamura, Y. Ellagic acid improves hepatic steatosis and serum lipid composition through reduction of serum resistin levels and transcriptional activation of hepatic ppara in obese, diabetic KK-Ay mice. Biochem. Biophys. Res. Commun. 2013, 434, 486-491. [CrossRef] [PubMed]

147. Panchal, S.K.; Ward, L.; Brown, L. Ellagic acid attenuates high-carbohydrate, high-fat diet-induced metabolic syndrome in rats. Eur. J. Nutr. 2013, 52, 559-568. [CrossRef] [PubMed]

148. Ahad, A.; Ganai, A.A.; Mujeeb, M.; Siddiqui, W.A. Ellagic acid, an NF-кB inhibitor, ameliorates renal function in experimental diabetic nephropathy. Chem. Biol. Interact. 2014, 219, 64-75. [CrossRef] [PubMed]

149. Karachanak-Yankova, S.; Dimova, R.; Nikolova, D.; Nesheva, D.; Koprinarova, M.; Maslyankov, S.; Tafradjiska, R.; Gateva, P.; Velizarova, M.; Hammoudeh, Z.; et al. Epigenetic alterations in patients with type 2 diabetes mellitus. Balkan J. Med. Genet. 2015, 18, 15-24. [CrossRef] [PubMed]

150. Paluszczak, J.; Krajka-Kuźniak, V.; Baer-Dubowska, W. The effect of dietary polyphenols on the epigenetic regulation of gene expression in MCF7 breast cancer cells. Toxicol. Lett. 2010, 192, 119-125. [CrossRef] [PubMed]

151. Holliday, R. Mechanisms for the control of gene activity during development. Biol. Rev. Camb. Philos. Soc. 1990, 65, 431-471. [CrossRef] [PubMed]

152. Choi, S.-W.; Claycombe, K.J.; Martinez, J.A.; Friso, S.; Schalinske, K.L. Nutritional Epigenomics: A Portal to Disease Prevention. Adv. Nutr. Int. Rev. J. 2013, 4, 530-532. [CrossRef] [PubMed]

153. Das, D.K.; Mukherjee, S.; Ray, D. Resveratrol and red wine, healthy heart and longevity. Heart Fail. Rev. 2010, 15, 467-477. [CrossRef] [PubMed] 
154. Lee, K.W.; Lee, H.J.; Lee, C.Y. Vitamins, phytochemicals, diets, and their implementation in cancer chemoprevention. Crit. Rev. Food Sci. Nutr. 2004, 44, 437-452. [CrossRef] [PubMed]

155. Link, A.; Balaguer, F.; Goel, A. Cancer chemoprevention by dietary polyphenols: Promising role for epigenetics. Biochem. Pharmacol. 2010, 80, 1771-1792. [CrossRef] [PubMed]

156. Hermsdorff, H.H.M.; Zulet, M.Á.; Puchau, B.; Martínez, J.A. Fruit and vegetable consumption and proinflammatory gene expression from peripheral blood mononuclear cells in young adults: A translational study. Nutr. Metab. (Lond.) 2010, 7, 42. [CrossRef] [PubMed]

157. Ambros, V. The functions of animal microRNAs. Nature 2004, 431, 350-355. [CrossRef] [PubMed]

158. Ambros, V.; Bartel, B.; Bartel, D.P.; Burge, C.B.; Carrington, J.C.; Chen, X.; Dreyfuss, G.; Eddy, S.R.; Griffiths-Jones, S.; Marshall, M.; et al. A uniform system for microRNA annotation. RNA 2003, 9, 277-279. [CrossRef] [PubMed]

159. Ross, S.A.; Davis, C.D. The emerging role of microRNAs and nutrition in modulating health and disease. Annu. Rev. Nutr. 2014, 34, 305-336. [CrossRef] [PubMed]

160. Tomé-Carneiro, J.; Larrosa, M.; Yáñez-Gascón, M.J.; Dávalos, A.; Gil-Zamorano, J.; Gonzálvez, M.; García-Almagro, F.J.; Ruiz Ros, J.A.; Tomás-Barberán, F.A.; Espín, J.C.; et al. One-year supplementation with a grape extract containing resveratrol modulates inflammatory-related microRNAs and cytokines expression in peripheral blood mononuclear cells of type 2 diabetes and hypertensive patients with coronary artery disease. Pharmacol. Res. 2013, 72, 69-82. [CrossRef] [PubMed]

161. Ortega, F.J.; Cardona-Alvarado, M.I.; Mercader, J.M.; Moreno-Navarrete, J.M.; Moreno, M.; Sabater, M.; Fuentes-Batllevell, N.; Ramírez-Chávez, E.; Ricart, W.; Molina-Torres, J.; et al. Circulating profiling reveals the effect of a polyunsaturated fatty acid-enriched diet on common microRNAs. J. Nutr. Biochem. 2015, 26, 1095-1101. [CrossRef] [PubMed]

162. Hernández-Alonso, P.; Giardina, S.; Salas-Salvadó, J.; Arcelin, P.; Bulló, M. Chronic pistachio intake modulates circulating microRNAs related to glucose metabolism and insulin resistance in prediabetic subjects. Eur. J. Nutr. 2016. [CrossRef] [PubMed]

163. Conlon, M.A.; Bird, A.R. The Impact of Diet and Lifestyle on Gut Microbiota and Human Health. Nutrients 2014, 7, 17-44. [CrossRef] [PubMed]

164. Ansell, J.; Parkar, S.; Paturi, G.; Rosendale, D.; Blatchford, P. Modification of the Colonic Microbiota. Adv. Food Nutr. Res. 2013, 68, 205-217. [PubMed]

165. Mandalari, G.; Faulks, R.M.; Bisignano, C.; Waldron, K.W.; Narbad, A.; Wickham, M.S.J. In vitro evaluation of the prebiotic properties of almond skins (Amygdalus communis L.). FEMS Microbiol. Lett. 2010, 304, 116-122. [CrossRef] [PubMed]

166. Ukhanova, M.; Wang, X.; Baer, D.J.; Novotny, J.A.; Fredborg, M.; Mai, V. Effects of almond and pistachio consumption on gut microbiota composition in a randomised cross-over human feeding study. Br. J. Nutr. 2014, 111, 2146-2152. [CrossRef] [PubMed]

167. Anhê, F.F.; Varin, T.V.; Le Barz, M.; Desjardins, Y.; Levy, E.; Roy, D.; Marette, A. Gut Microbiota Dysbiosis in Obesity-Linked Metabolic Diseases and Prebiotic Potential of Polyphenol-Rich Extracts. Curr. Obes. Rep. 2015, 4, 389-400. [CrossRef] [PubMed]

168. Anhê, F.F.; Roy, D.; Pilon, G.; Dudonné, S.; Matamoros, S.; Varin, T.V.; Garofalo, C.; Moine, Q.; Desjardins, Y.; Levy, E.; et al. A polyphenol-rich cranberry extract protects from diet-induced obesity, insulin resistance and intestinal inflammation in association with increased Akkermansia spp. population in the gut microbiota of mice. Gut 2015, 64, 872-883. [PubMed]

169. Nieman, D.C.; Scherr, J.; Luo, B.; Meaney, M.P.; Dréau, D.; Sha, W.; Dew, D.A.; Henson, D.A.; Pappan, K.L. Influence of pistachios on performance and exercise-induced inflammation, oxidative stress, immune dysfunction, and metabolite shifts in cyclists: A randomized, crossover trial. PLoS ONE 2014, 9, e113725. [CrossRef] [PubMed]

170. Hernández-Alonso, P.; Cañueto, D.; Giardina, S.; Salas-Salvadó, J.; Cañellas, N.; Correig, X.; Bulló, M. Effect of pistachio consumption on the modulation of urinary gut microbiota-related metabolites in pre-diabetic subjects. J. Nutr. Biochem. 2017, 45, 48-53. [CrossRef] [PubMed]

(C) 2017 by the authors. Licensee MDPI, Basel, Switzerland. This article is an open access article distributed under the terms and conditions of the Creative Commons Attribution (CC BY) license (http:/ / creativecommons.org/licenses/by/4.0/). 